Supporting Information

\title{
Wood-Based Flexible Electronics
}

Qiliang Fu*, Yi Chen and Mathias Sorieul

Scion, 49 Sala Street, Rotorua 3020, New Zealand

*Corresponding author. Email: qiliang.fu@scionresearch.com

This PDF file of Supporting Information includes:

Supplementary Methods and Experiments

Supplementary Text

Supplementary Figures S1 to S26

Supplementary Tables S1 to S5

References 


\section{Supplementary Methods and Experiments}

CNF nanopaper preparation. Cellulose nanofibrils (CNF, BioplusTM cellulose nanofibrils, 3 wt \% solids) was obtained from American Processing Inc (USA). The CNF suspension was filled into a $14 \mathrm{~cm}$ diameter petri dish and dried over $48 \mathrm{~h}$ in ambient conditions to form a CNF nanopaper. The dried CNF film was peeled off from the dish for further assessment. $2 D$ NMR for $T_{1 \rho} H$ constant. Carbon spectrum of lignin derived carbon fibers (LCF) were collected on a Bruker 200 Advance III spectrometer at a proton frequency of $200.13 \mathrm{MHz}$, and a carbon frequency of $50.32 \mathrm{MHz}$ fitted with a $4 \mathrm{~mm}$ broadband SB MAS probe (Bruker, Germany). The sample was packed into a $4 \mathrm{~mm} \mathrm{ZrO}_{2}$ rotor and spun at $5 \mathrm{kHz}$. Cross-polarization magic angle spinning experiments had a $3.5 \mu \mathrm{s} 90^{\circ}{ }^{1} \mathrm{H}$ preparation pulse followed by different contact times, and $26 \mathrm{~ms}$ acquisition with high-powered decoupling. The spectra were then Fourier transformed. Six contact time experiments were chosen, $0.5 \mathrm{~ms}, 1 \mathrm{~ms}, 2 \mathrm{~ms}, 4 \mathrm{~ms}, 6 \mathrm{~ms}$, $8 \mathrm{~ms} . T_{1 \rho} H$ constant was calculated by Bruker Dynamics Center v.2.5.4 for each peak, picked manually, using the peak intensities to calculate $T_{1 \rho} H$ from Equation (1), $f(t)=I_{0} e^{\wedge}\left(-t / T_{1 \rho}\right)$ to fit $I_{0}$ and $T_{1 \rho} H$,

Raman Spectrum. The carbonaceous structure of carbon fiber derived from lignin was characterised by Raman spectroscopy. The spectrum was collected by Ramanstation 400 instrument (PerkinElmer, USA) equipped with a $785 \mathrm{~nm}$ near infrared laser. The laser power was set to $20 \mathrm{~mW}$ and the exposure time was $60 \mathrm{~s}$.

Pore volume and distribution. The Brunauer-Emmett-Teller (BET) nitrogen absorption was carried out with a Micromeritics ASAP 2020 instrument to get the pore size distribution of the test sample. Samples were degassed at $70{ }^{\circ} \mathrm{C}$ for $24 \mathrm{~h}$, followed by analysis at $-196{ }^{\circ} \mathrm{C}$ by $\mathrm{N}_{2}$ physisorption. The data were collected at a relative pressure between 0.1 and 0.3 .

Porosity. Porosity was estimated from the dried sample mass and the solid cellulose or wood sample according to the following Equation (2),

Porosity $=\left(1-\frac{\rho_{t}}{\rho_{*}}\right) \times 100 \%$, 
Where $\rho_{t}$ and $\rho_{*}$ are the density of the test sample and solid cellulose or wood sample, respectively. $\rho_{*}$ is $1.5 \mathrm{~g} \mathrm{~cm}^{-3}$, according to the reference from L. Gibson. ${ }^{1}$

Water contact angle. The contact angles of water on the wood surface were measured by a FTA1000B automated drop shape analyser.

Moisture Content. The samples were conditioned at 30\%, 50\%, 75\% and 95\% relative humidity in a chamber (Climates EXCAL Environmental test chamber, France) at $23 \pm 1{ }^{\circ} \mathrm{C}$ for $48 \mathrm{~h}$ until reached equilibrium. The final weight of the samples was recorded. The moisture content was calculated from the following Equation (4),

Moisture content $=\left[\left(W_{a}-W_{d}\right) / W_{d}\right] \times 100 \%$,

where $W_{a}$ is the sample weight when the sample was conditioned in the corresponding relative humidity until a constant value was reached, and $W_{d}$ is the dry sample weight.

Surface roughness measurement. It is crucial to evaluate the surface roughness of a substrate for electronics as it influences the adhesion of the ink/conductive layers. The surface evaluation of TWF was performed by using a 3D optical profilometer (Filmetrics Inc.).

Sheet resistance measurement. It is often necessary to measure the resistivities of thin films or sheets for the electronics. The sheet resistance can be calculated by the following Equation (3), $R_{s}=1 /(\sigma h) ; \sigma=1 / \rho ; \rho=R w h / l$,

Where $R_{S}(\Omega /$ squ. $)$ is the sheet resistance. $h, w$ and $l$ are the film thickness, width and length, respectively. $\sigma$ is the conductivity of the film. $R$ is the measurement value of resistance. 


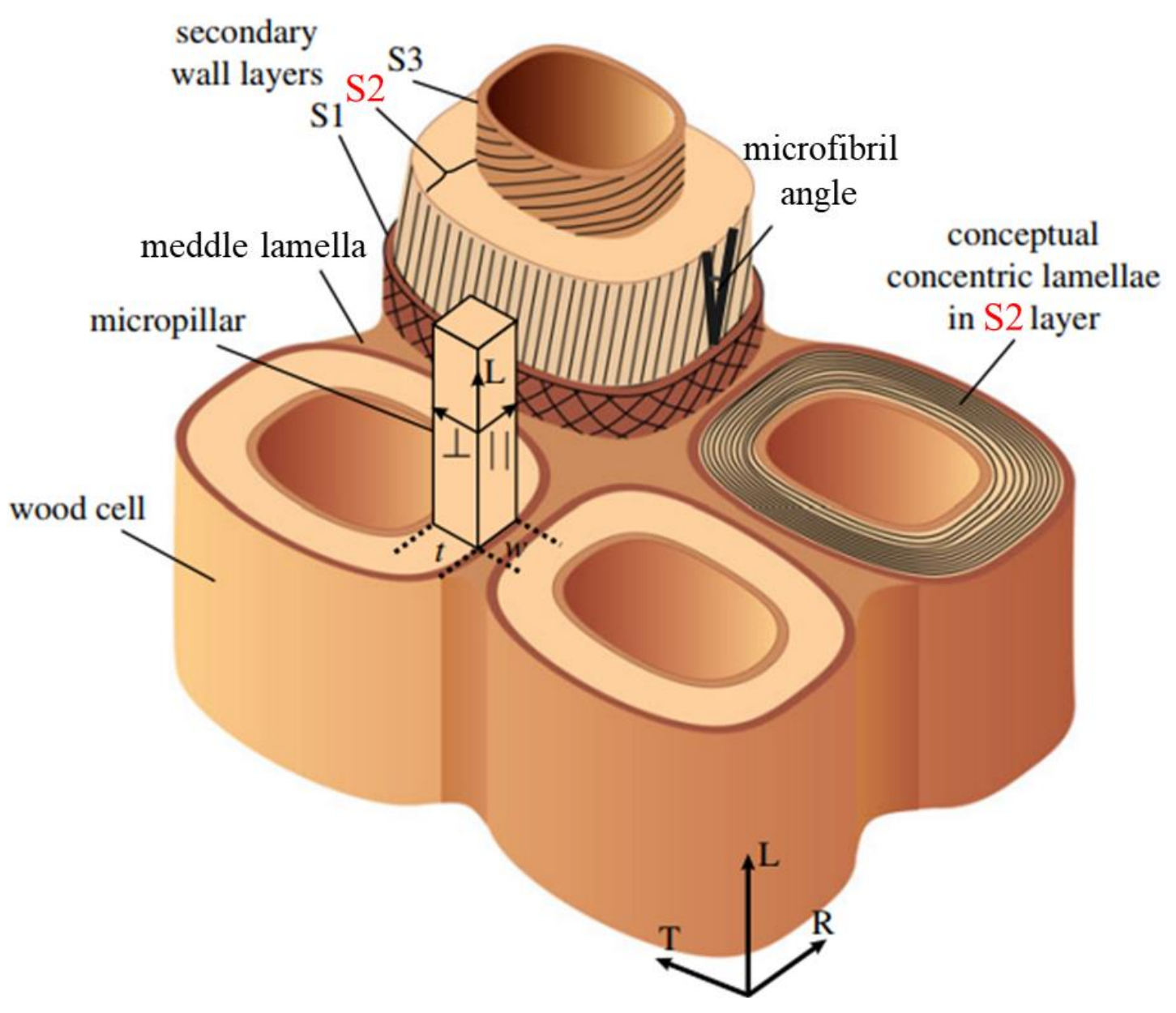

Figure S1. Schematic representation of cell wall layers hierarchical structure. A single cell wall is typically made of primary wall and secondary wall. Three sub-layers (S1, S2 and S3) constitute the secondary wall. The S2 layers form around $85 \mathrm{vol} \%$ of the secondary cell wall. The S2 layer has highly aligned cellulose nanofibrils along the longitudinal (L) direction. ${ }^{2}$ (C) Copyright of The Royal Society 2014) 

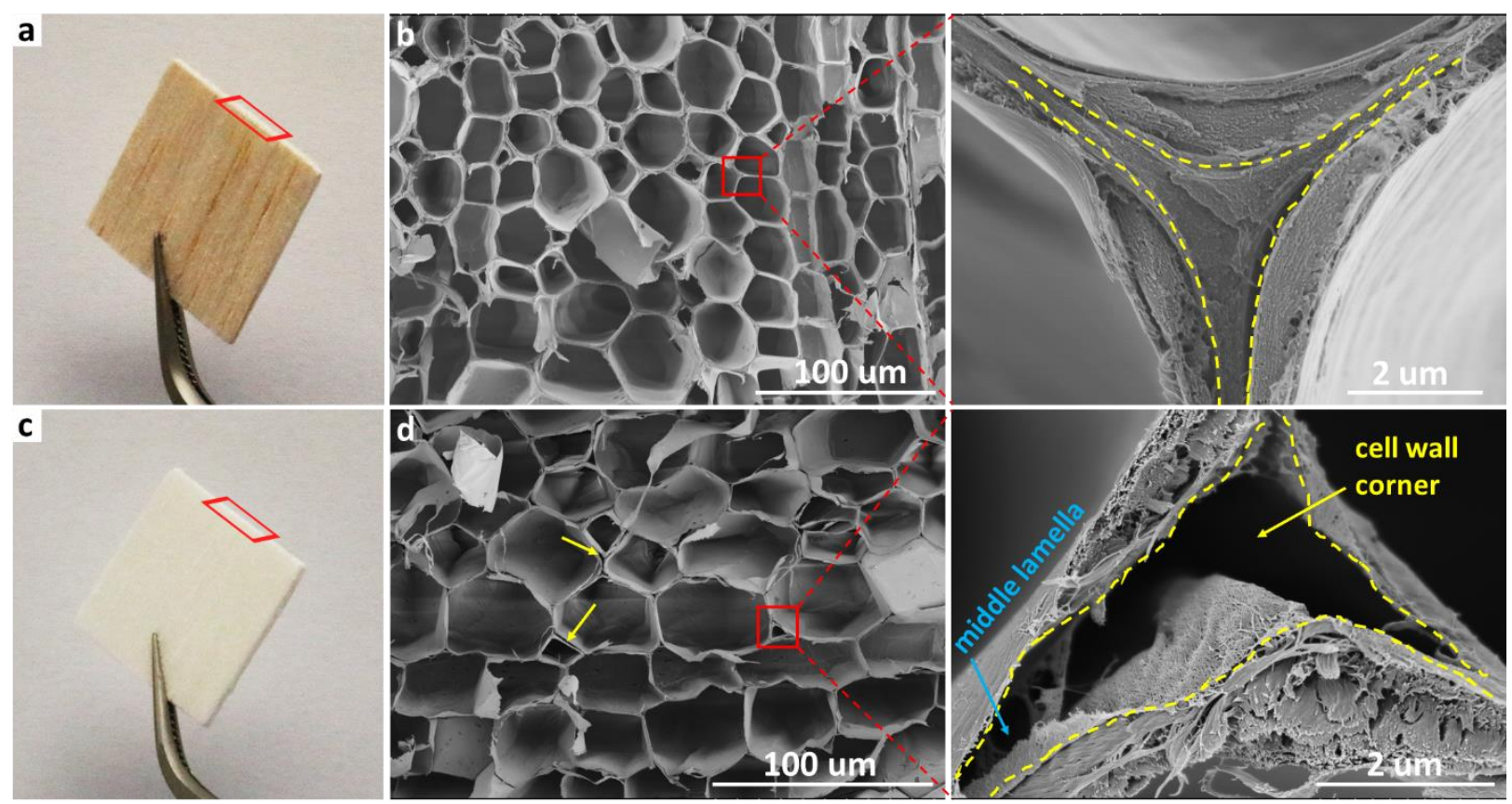

Figure S2. Hierarchical structure of wood materials demonstrated by digital photos and crosssectional field emission SEM images. (a) Photograph of original balsa wood and (b) its crosssectional SEM images at low and high magnification. The space between the yellow dashed lines in high magnification image (b) shows the lignin rich cell wall corner and middle lamella. (c) Digital photograph of treated wood and (d) its cross-sectional SEM images at low and high magnification. The empty space between yellow dash lines (d) indicates the empty spaces left after removal of cell wall components from the cell wall corner (yellow arrow) and middle lamella (blue arrow) by the chemical treatment. 


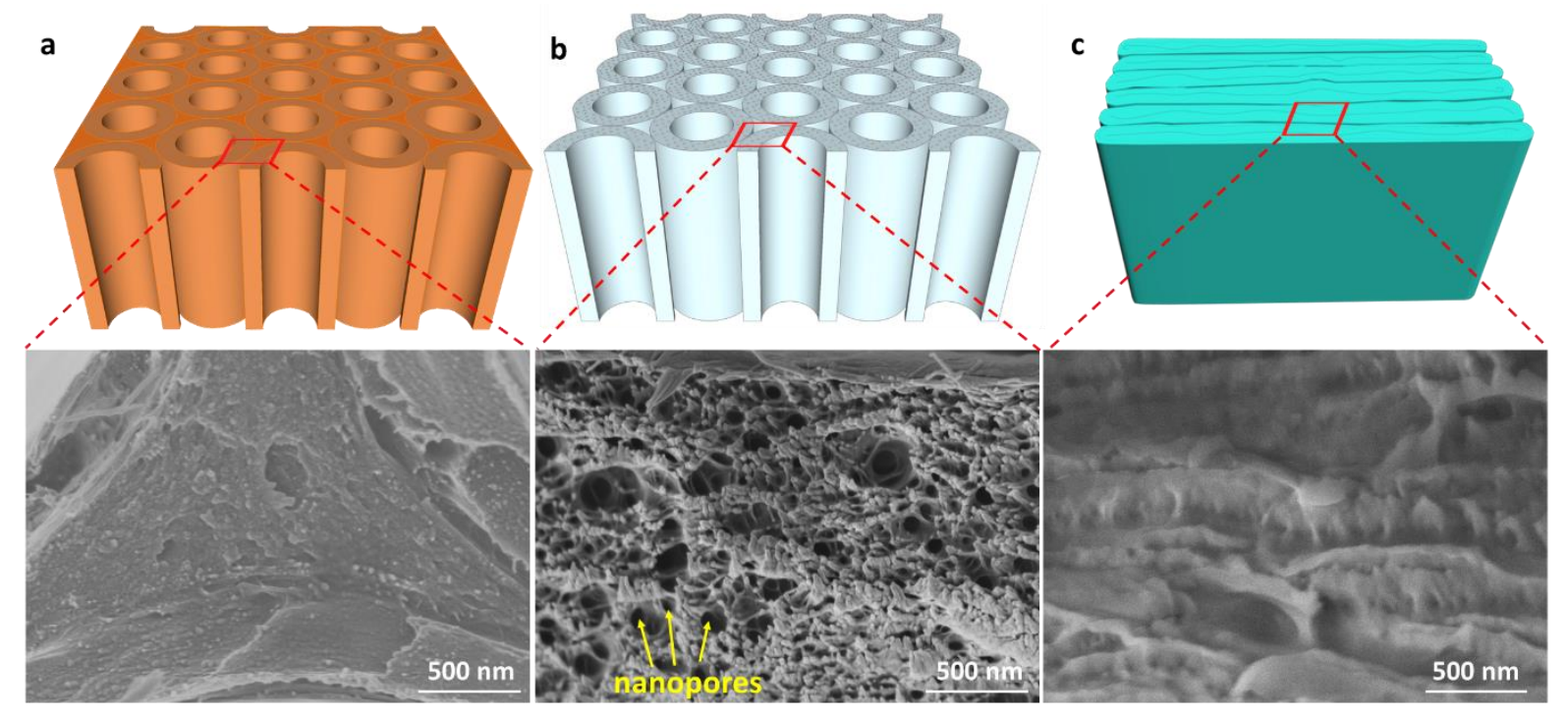

Figure S3. Schemes and SEM images of cell walls: (a) original wood, (b) treated wood and (c) TWF. (a) Wood components are fully embedded in the cell wall. (b) Nanopores (yellow arrows) are generated inside the cell wall due to removal of lignin and hemicelluloses. (c) After compression the collapsed cell walls are bonded together resulting in formation a laminated layer structure. 

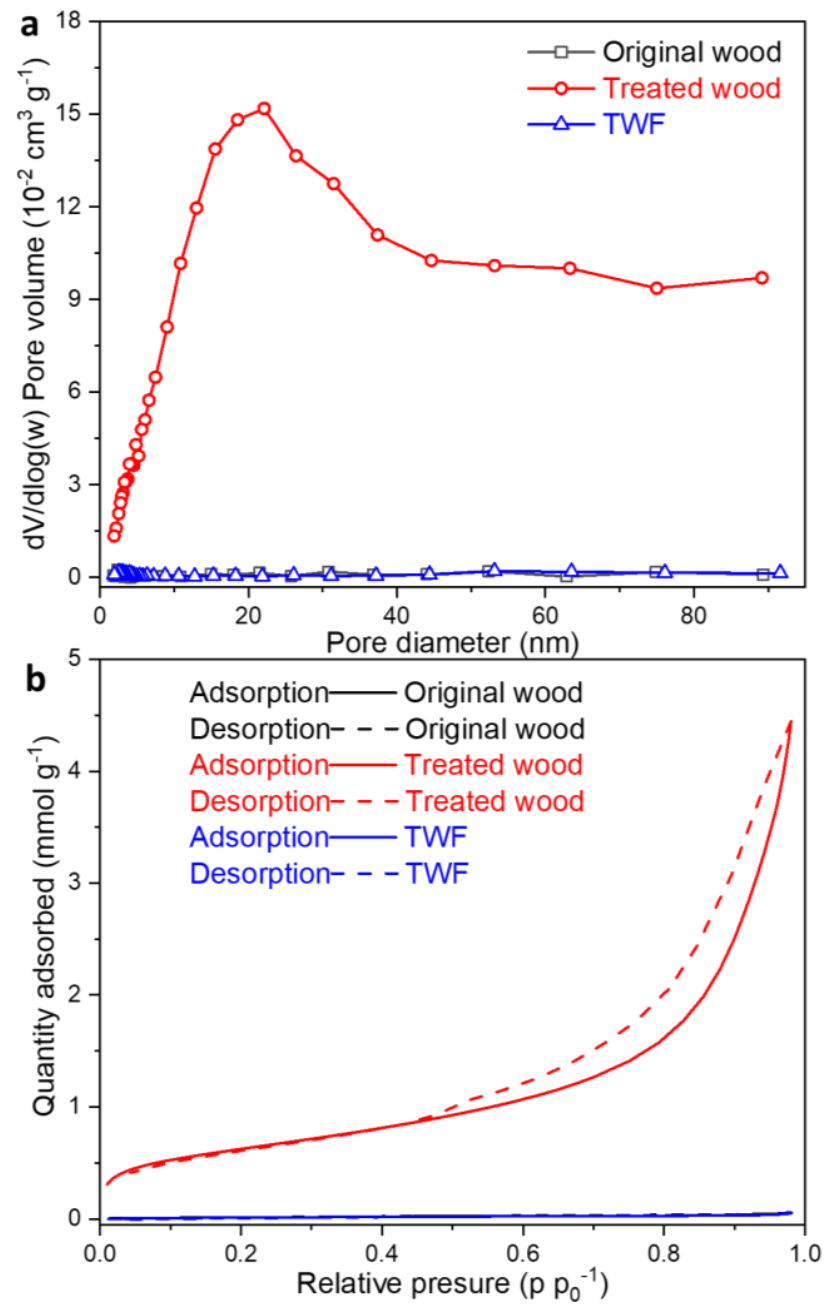

Figure S4. Pore size distribution and physical gas absorption/desorption from BET desorption analysis. (a) Pore volume distributions and (b) $\mathrm{N}_{2}$ adsorption/desorption isotherms of original wood, treated wood and TWF.

The BET surface area of the treated wood $\left(49.7 \mathrm{~m}^{2} \mathrm{~g}^{-1}\right)$ significantly increases compared to that of original wood $\left(1.1 \mathrm{~m}^{2} \mathrm{~g}^{-1}\right)$ due to nano-scale pores generated in the cell wall after chemical treatment. The Specific surface area of TWF $\left(0.5 \mathrm{~m}^{2} \mathrm{~g}^{-1}\right)$ is slightly lower than that of native balsa wood. Compared to treated wood, however, the value of specific surface area of TWF is dramatically decreased from $49.7 \mathrm{~m}^{2} \mathrm{~g}^{-1}$ to $0.5 \mathrm{~m}^{2} \mathrm{~g}^{-1}$ because of compression process that removal of micro- and nano- scale pores from the cell wall. 
Table S1. Porosity and thickness variation.

\begin{tabular}{|c|c|c|c|c|}
\hline Materials & $\begin{array}{c}\text { BET surface area } \\
\left(\mathrm{m}^{2} \mathrm{~g}^{-1}\right)\end{array}$ & Porosity (\%) & $\begin{array}{c}\text { Thickness } \\
(\mu \mathrm{m})\end{array}$ & $\begin{array}{c}\text { Thickness } \\
\text { change }(\%)\end{array}$ \\
\hline Original wood & 1.1 & 88.5 & $1000 \pm 25$ & N/A \\
\hline Treated wood & 49.7 & 94.4 & $1150+86$ & $+15 \%$ \\
\hline TWF & 0.5 & 24 & $55 \pm 20$ & $-94.5 \%$ \\
\hline
\end{tabular}

"N/A": not applicable. 

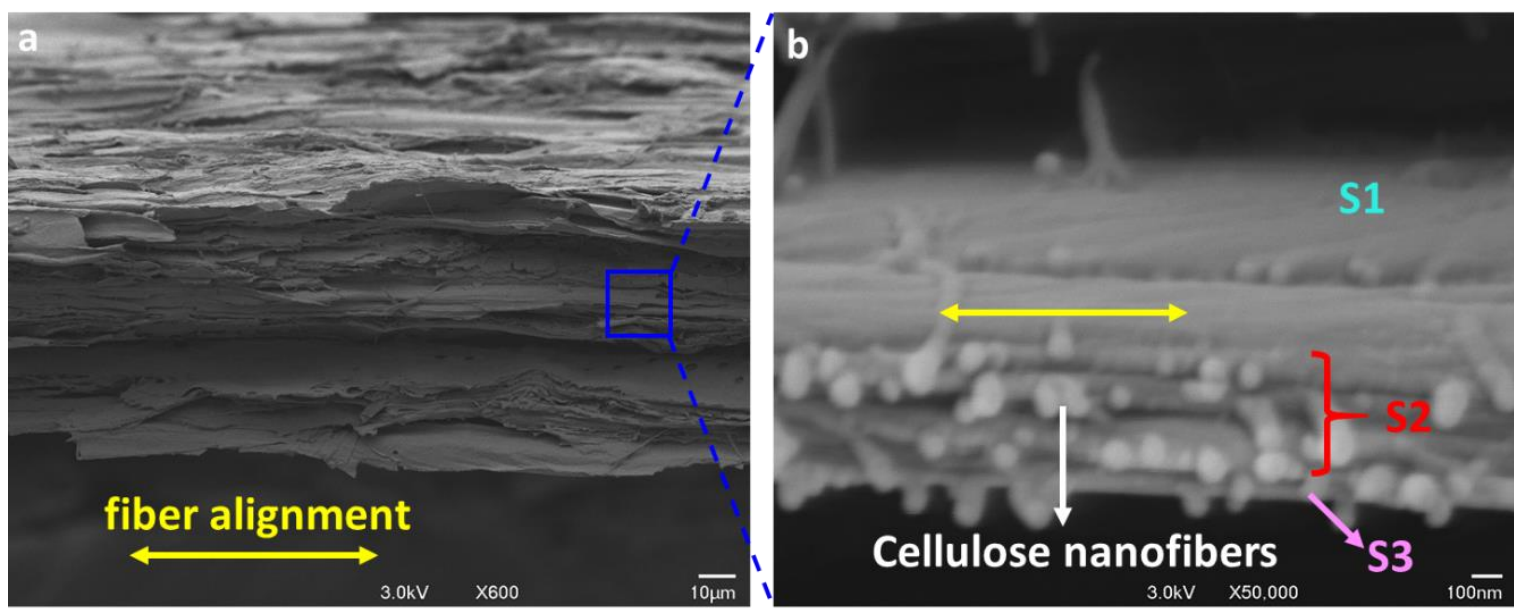

Figure S5. SEM images obtained from TWF edge side. (a) Laminate structure with microfiber alignment. (b) Highly aligned cellulose nanofiber orientations in three different layers (S1, S2 and S3) within the cell wall. The CNF orientation of S1 and S3 layer is almost perpendicular to the tree growth direction. The secondary S2 layer has low microfibril angle with highly aligned cellulose along the tree growth direction (Figure S1). 


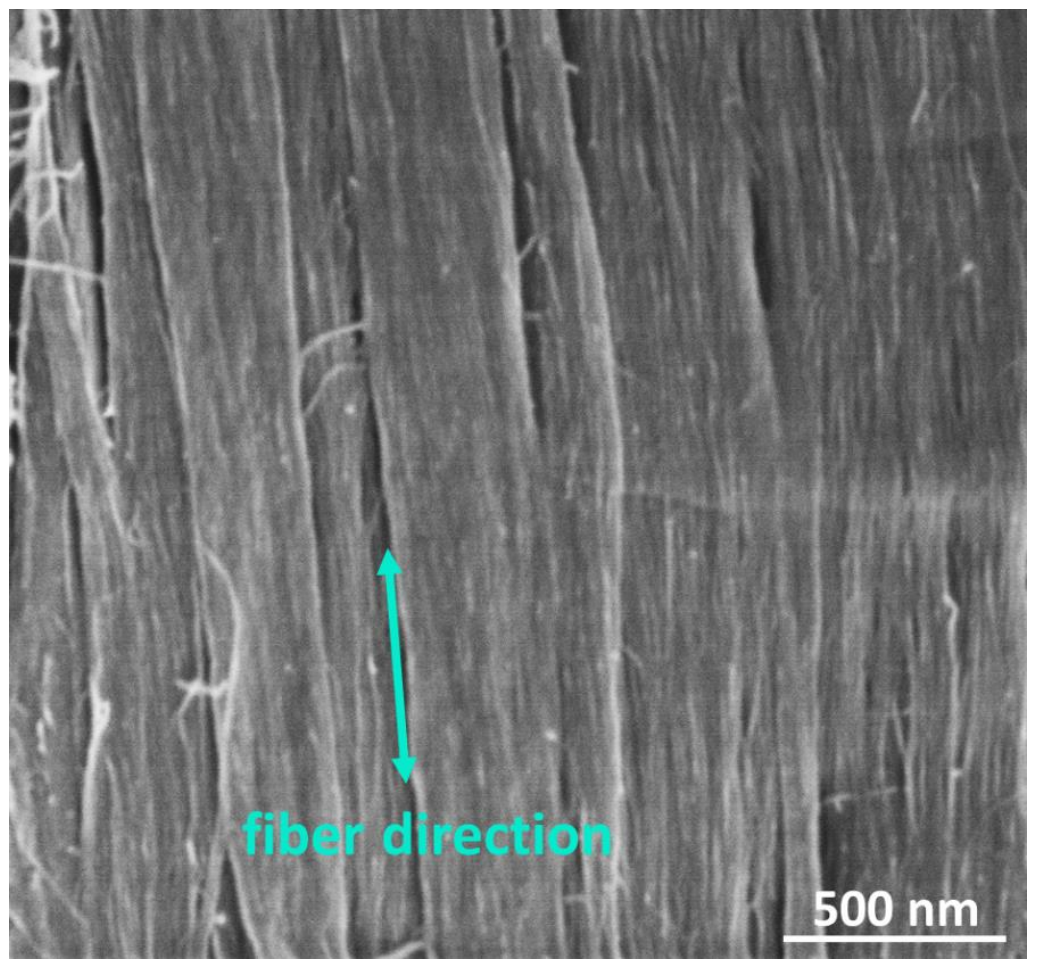

Figure S6. SEM image of the secondary cell wall of TWF surface shows the aligned cellulose microfiber bundles. 

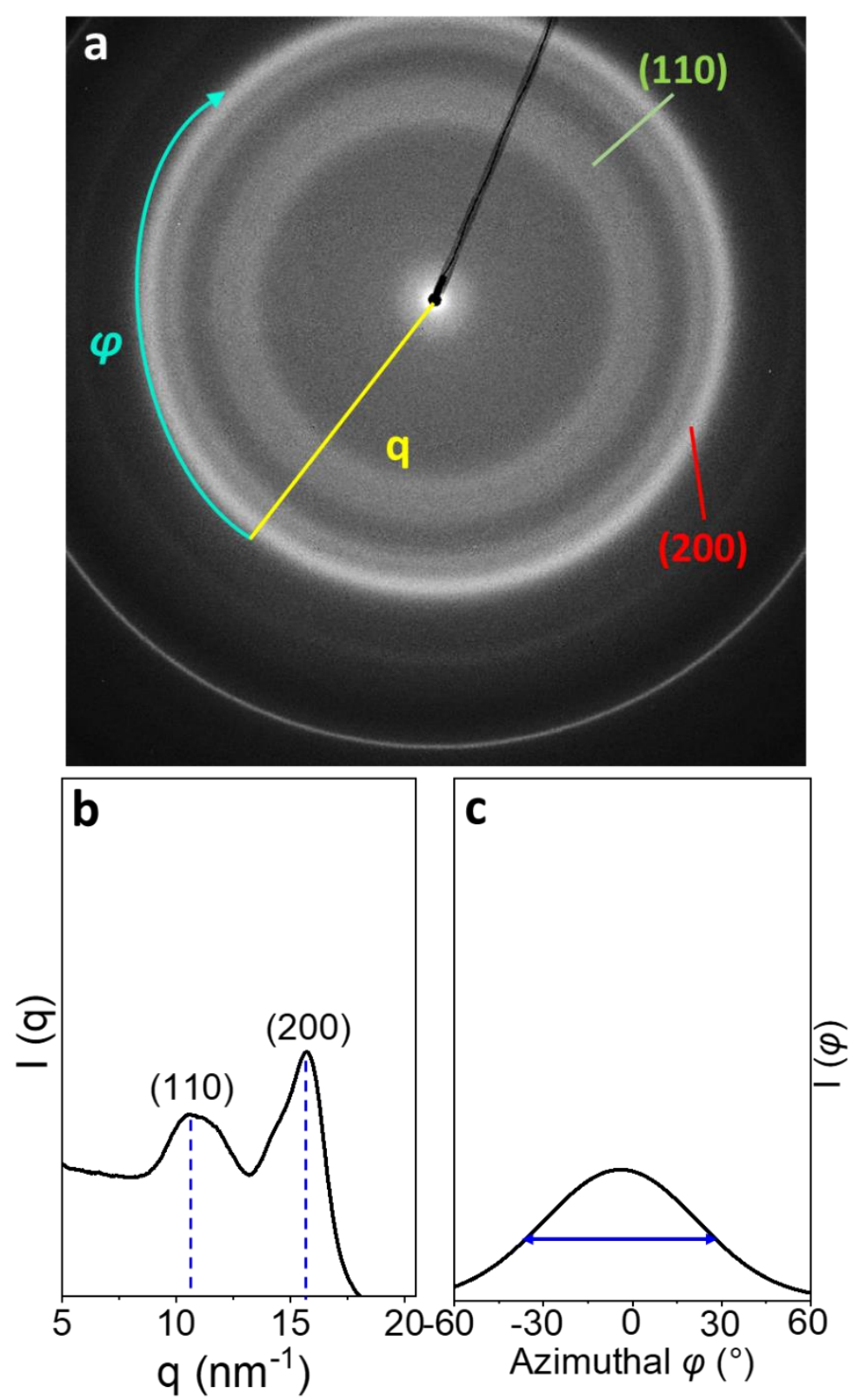

Figure S7. (a) WAXS scattering diffractogram of randomly distributed CNF nanopaper. (b) Radial integration of the diffractogram shown in (a). (c) Azimuthal integration of the (200) scattering plane of the diffractogram shown in (a).

The distribution of cellulose fibril alignment, as judged from the constant width of arcing of Bragg peaks in the WAXS data from crystalline cellulose domains. The two-dimensional scattering patterns were averaged radially resulting in intensities $\mathrm{I}(q)$. The radial distance from the beam centre was converted to the scattering vector amplitude using Equation (6),

$q=\frac{4 \pi \sin \theta}{\lambda} ; s=\frac{2 \sin \theta}{\lambda}=\frac{q}{2 \pi}=\frac{1}{d} ; \theta=\frac{1}{2} \arctan \left(\frac{r}{L}\right)$, 
Where $q$ and $s$ are the absolute value of the scattering vector and magnitude scattering vector, respectively. $\lambda$ and $2 \theta$ are the wavelength and the scattering angle respectively. $d$ is the crystallographic d-spacing. $r$ is the distance from the beam centre on the flat detector positioned perpendicular to the beam and $L$ is the sample-to-detector distance.

Two orientation factors, namely the orientation index $(f)$ and Hermans orientation parameter $(S)$, are calculated and assessed the degree of cellulose orientation (Equation 7).

$f=\frac{180-F W H M}{180}$,

FWHM is the full width at half maximum, using Gaussian peak fitting of the X-ray curve. The orientation indexes are 0.89 and 0.66 for TWF and CNF nanopaper, respectively The alignment of CNF is quantified by converting the orientation distribution in terms of order parameter $(S)$, defined as Equation (8) and (9).

$$
\begin{aligned}
& S=\left(\frac{3}{2} \cos ^{2} \varphi-\frac{1}{2}\right), \\
& \left\langle\cos ^{2} \varphi\right\rangle=\frac{\sum_{0}^{\pi / 2} I(\varphi) \sin \varphi \cos ^{2} \varphi d \varphi}{\sum_{0}^{\pi / 2} I(\varphi) \sin \varphi d \varphi},
\end{aligned}
$$

Where $S$ is the order parameter. $\varphi$ is the azimuthal angle in a diffractogram. $I(\varphi)$ is the intensity distribution averaged along examined $q$ value for each azimuthal angle. 


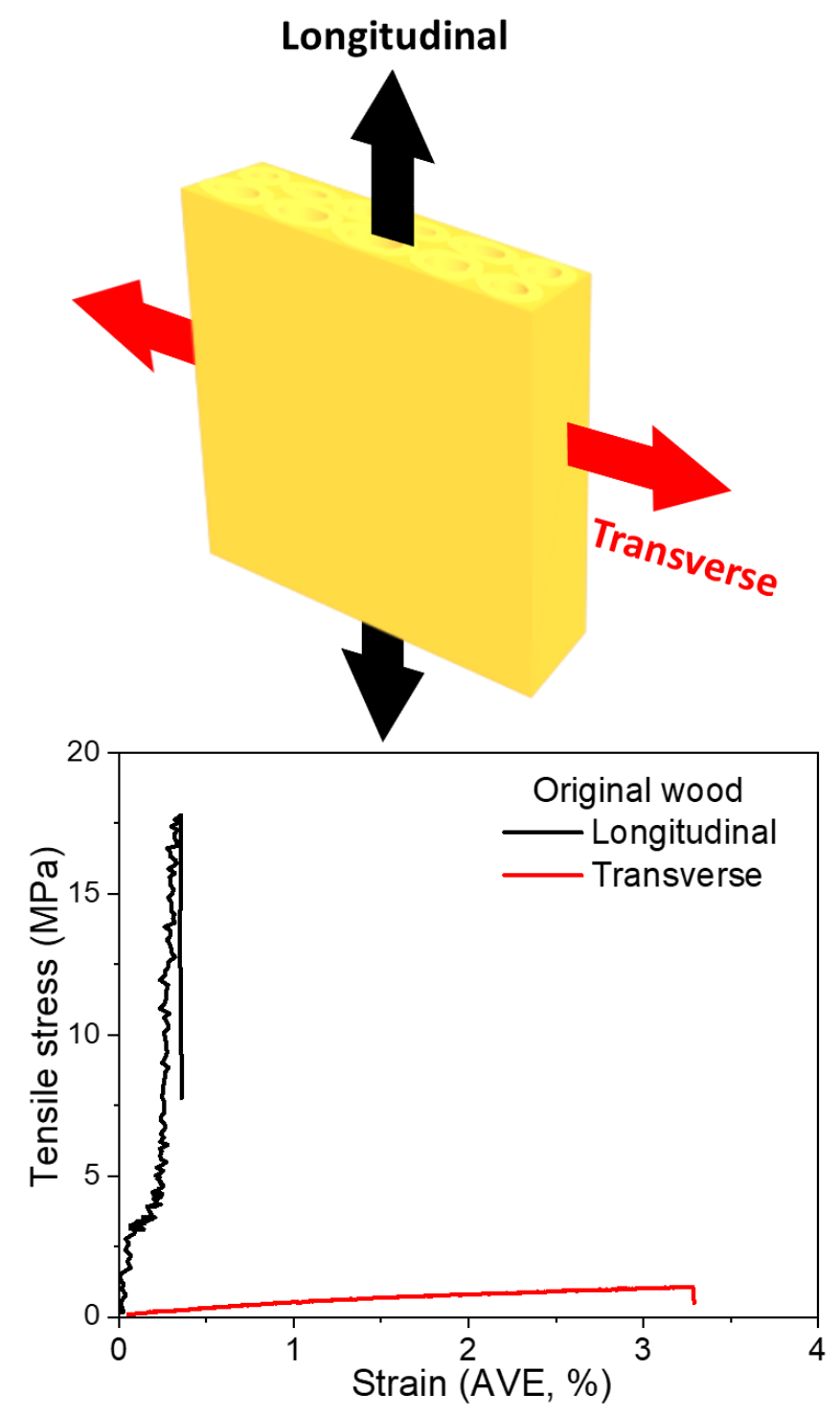

Figure S8. Snapshot and the stress-strain curve of original wood in longitudinal and transverse directions. 

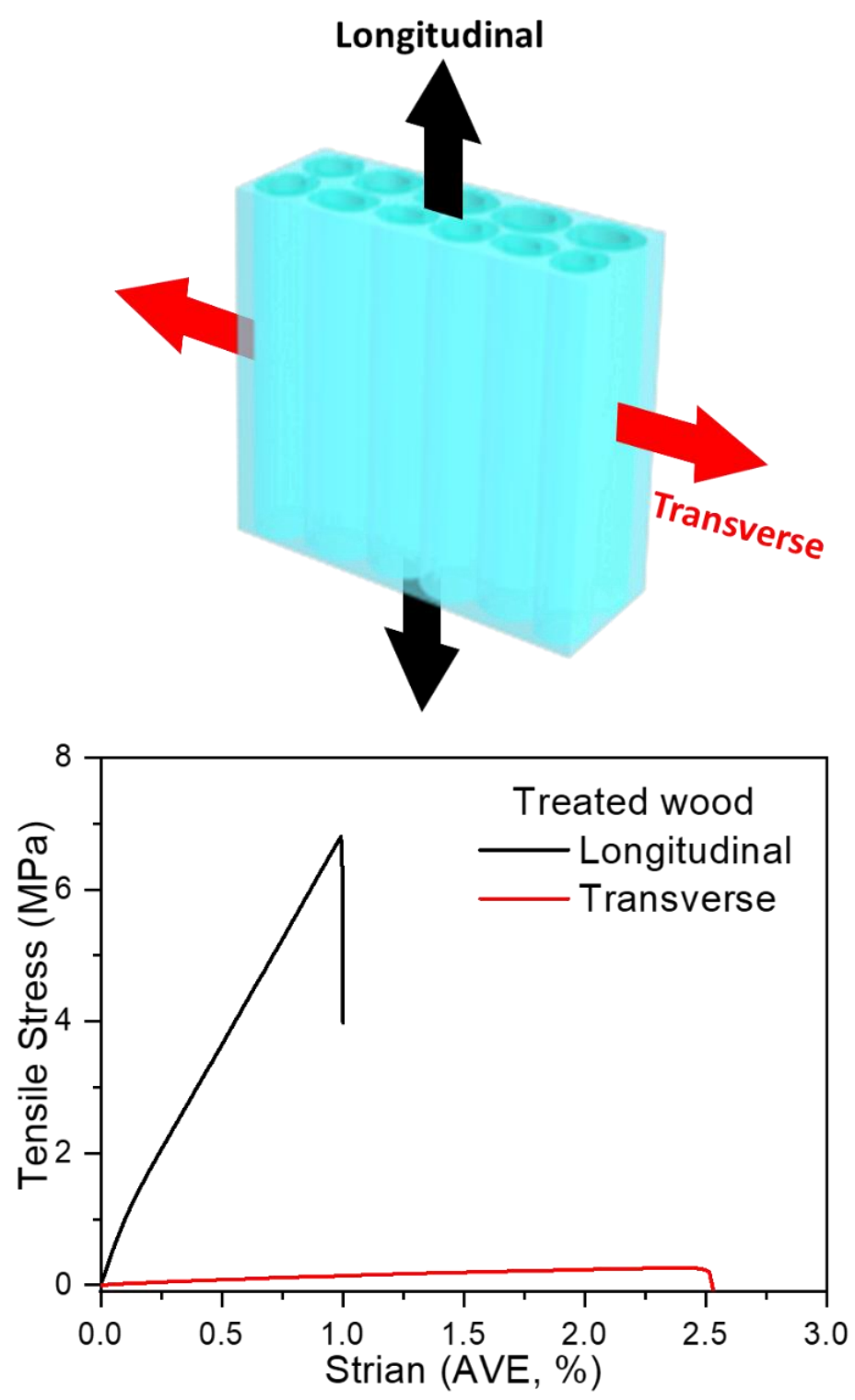

Figure S9. Snapshot and the stress-strain curve of treated wood in longitudinal and transverse directions. 


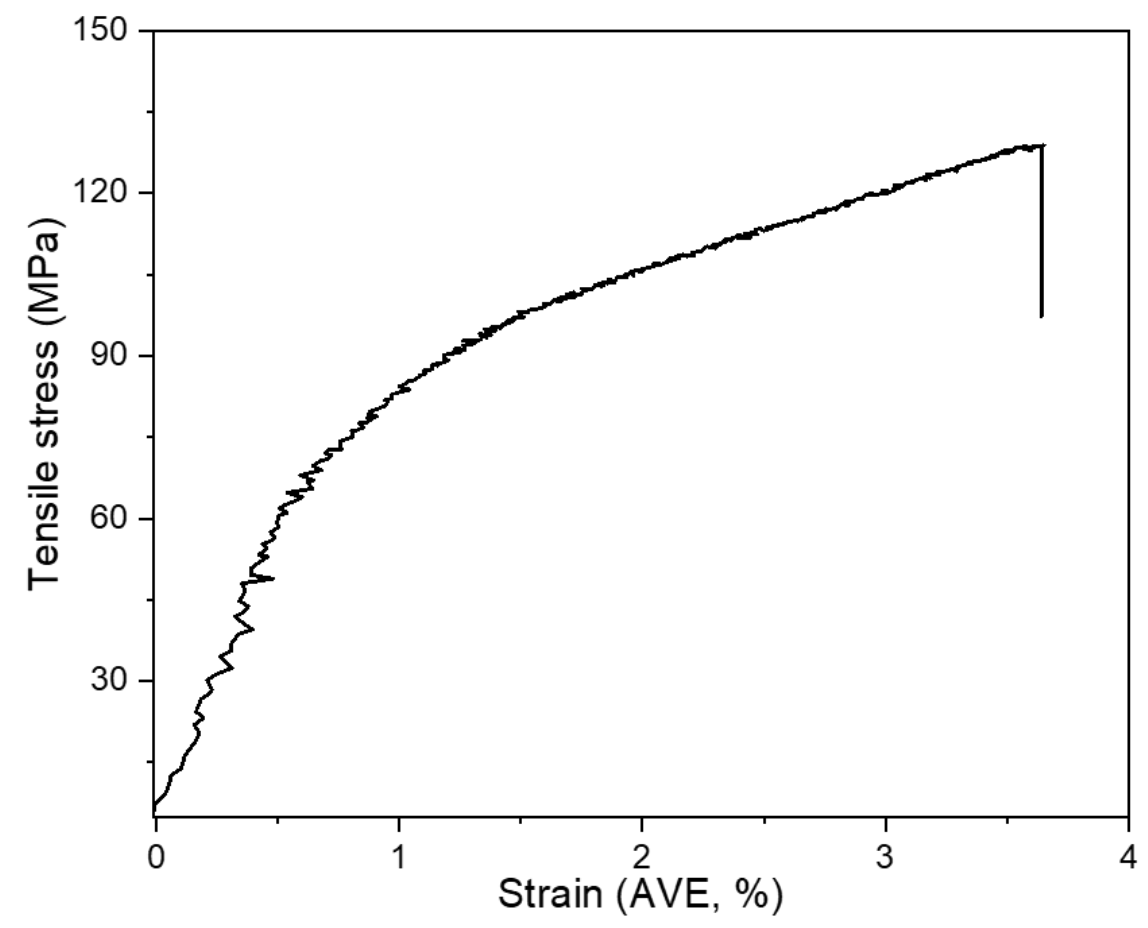

Figure S10. Typical stress-strain curve of a TWF sample tested in transverse direction (perpendicular to the nanofiber growth direction).

The Young's modulus and strength of TWF in transverse direction are $10.6 \mathrm{GPa}$ (specific $E=$ 8.8 $\mathrm{GPa} \mathrm{cm}^{3} \mathrm{~g}^{-1}$ ) and 128.5 $\mathrm{MPa}$ (specific $\sigma=107.1 \mathrm{MPa} \mathrm{cm}^{3} \mathrm{~g}^{-1}$ ), respectively (Tables $\mathrm{S} 2-3$ ), those values are higher than most natural fiber based materials, petroleum-based polymers and plastics. The main reason could be explained by the fact that the intramolecular and created intermolecular hydrogen bonds are well placed to resist the straightening and consequent elongation of the TWF resulting in an improvement of modulus and strength compared to natural and treated wood. 


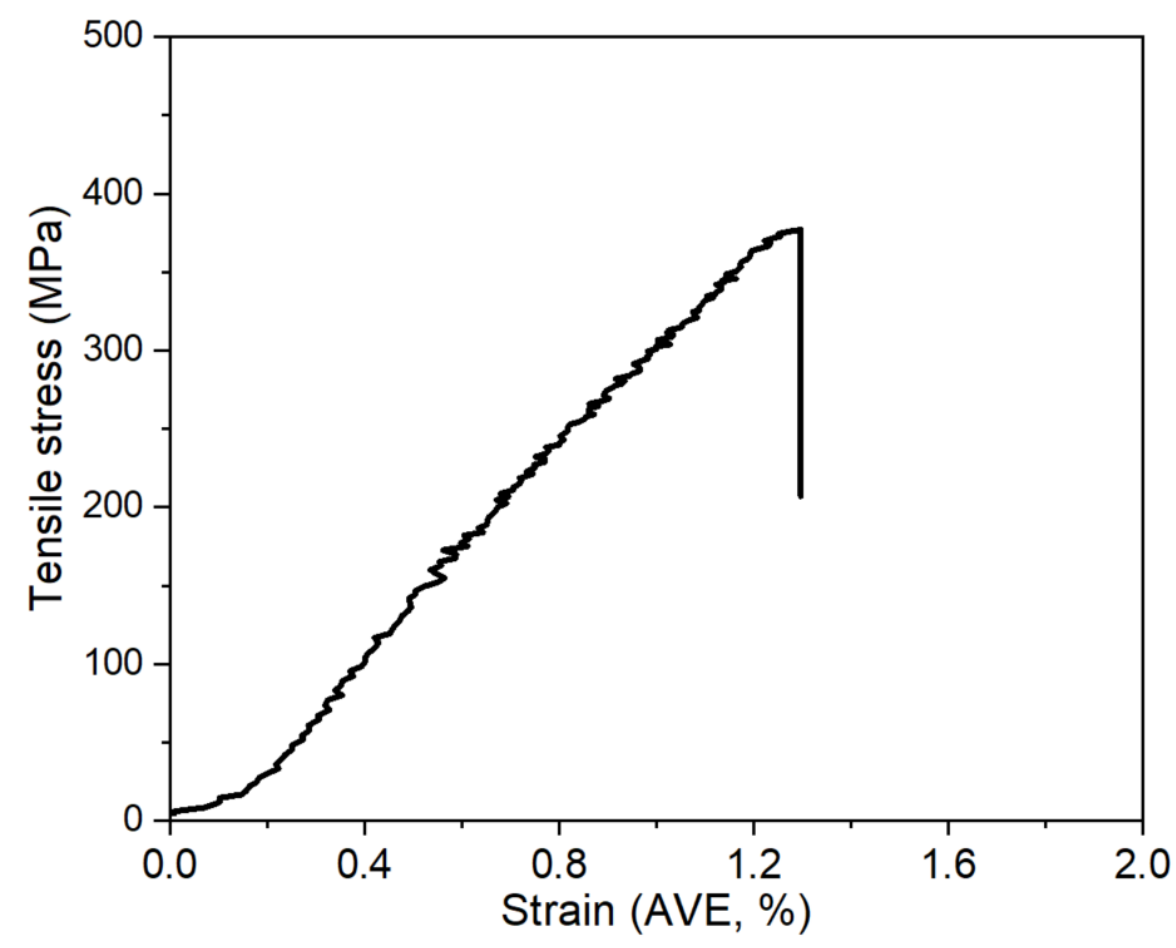

Figure S11. Typical stress-stain curve of a transparent film after 3-5 h of sodium hypochlorite treatment.

Comparison with a different chemical treatment of balsa wood, the wood samples were immersed in a sodium hypochlorite solution for $3-5 \mathrm{~h}(5.3 \mathrm{wt} \%)$. Once the wood slices turned white, they were washed three times with a solution of water and ethanol $(1: 1, \mathrm{w} / \mathrm{w}) .^{3}$ The pretreated wood samples were then covered with polyethersulfone film and filter paper. Finally, they were pressed with $1-5 \mathrm{~kg}$ for $24 \mathrm{~h}$ to obtain the TWF. The modulus and strength of the obtained material are $38.3 \mathrm{GPa}$ and $378.4 \mathrm{MPa}$ respectively, which are slightly higher than transparent film prepared with the same chemical reaction but with basswood. ${ }^{3}$ This could be due to the different wood species, and high cellulose crystallinity of balsa wood. ${ }^{4}$ However, the mechanical properties of the TWF treated by sodium hypochlorite are lower than after a sodium chlorite treatment, this could be attributed to a partial degradation of the cellulose during sodium hypochlorite treatment. 
Table S2. Summary of the aligned wood, densified wood and cellulose-based materials mechanical properties.

\begin{tabular}{|c|c|c|c|c|c|c|c|}
\hline \multirow[t]{2}{*}{ Material } & \multirow{2}{*}{$\begin{array}{l}\text { Preparation method } \\
\text { or alignment } \\
\text { method }\end{array}$} & \multirow[t]{2}{*}{$\begin{array}{l}\text { Density } \\
\left(\mathrm{g} \mathrm{cm}^{-3}\right)\end{array}$} & \multicolumn{2}{|c|}{$\begin{array}{c}\text { Young's } \\
\text { modulus } E(\mathrm{GPa})\end{array}$} & \multicolumn{2}{|c|}{ Strength $\sigma(\mathrm{MPa})$} & \multirow[t]{2}{*}{ Ref. } \\
\hline & & & $\|$ & $\perp$ & $\|$ & $\perp$ & \\
\hline TWF & $\begin{array}{c}\text { Pre-treatment and } \\
\text { pressing }\end{array}$ & $1.2 \pm 0.1$ & $\begin{array}{r}49.9 \\
\pm 10.8\end{array}$ & $\begin{array}{l}10.6 \\
\pm 1.2\end{array}$ & $\begin{array}{r}469.9 \\
\pm 114.3\end{array}$ & $\begin{array}{l}128.5 \\
\pm 19.7\end{array}$ & This work \\
\hline CNF nanopaper & $\begin{array}{l}\text { Randomly } \\
\text { distributed }\end{array}$ & 1.2 & 14.9 & & 243 & & 5 \\
\hline CNF-g-PEG & $\begin{array}{c}\text { Grafting and } \\
\text { stretching alignment }\end{array}$ & 1.31 & 32.3 & & 576 & & 6 \\
\hline $\begin{array}{l}\text { Cellulose film } \\
\text { (Ramie) }\end{array}$ & $\begin{array}{l}\text { Delignified, } \\
\text { manually aligned } \\
\text { and compression }\end{array}$ & 1.54 & 39.7 & & 620 & & 7 \\
\hline Holocellulose film & Shear oriented & 1.2 & 27 & 2.1 & 260 & 21 & 8 \\
\hline CNC-CMC film & $\begin{array}{l}\text { Stretching } \\
\text { alignment }\end{array}$ & & 15 & & 187 & & 9 \\
\hline CNF macrofiber & Wet Stretching & 1.5 & 33.7 & & 289 & & 10 \\
\hline CNF nanopaper & Wet stretching & & 33 & & 430 & & 11 \\
\hline $\begin{array}{c}\text { Bacterial cellulose } \\
\text { macrofiber }\end{array}$ & $\begin{array}{l}\text { Wet spinning, } \\
\text { stretching and } \\
\text { cross-linking }\end{array}$ & & 22.9 & & 357.5 & & 12 \\
\hline $\begin{array}{c}\text { Bacterial cellulose } \\
\text { macrofiber }\end{array}$ & $\begin{array}{c}\text { Wet stretching and } \\
\text { twisting }\end{array}$ & 1.38 & 65.7 & & 825.5 & & 13 \\
\hline CNF filament & $\begin{array}{c}\text { Hydrodynamic } \\
\text { alignment }\end{array}$ & 1.5 & 18 & & 490 & & 14 \\
\hline
\end{tabular}




\begin{tabular}{|c|c|c|c|c|c|c|c|}
\hline CNF macrofiber & $\begin{array}{l}\text { Hydrodynamic } \\
\text { alignment and } \\
\text { cross-linking }\end{array}$ & 1.5 & 86 & & 1570 & & 15 \\
\hline Transparent film & $\begin{array}{l}\text { Chemical treatment } \\
\text { and compression }\end{array}$ & 1.31 & & & 350 & 23.2 & 3 \\
\hline $\begin{array}{l}\text { Densified wood } \\
\text { film }\end{array}$ & $\begin{array}{l}\text { Chemical treatment } \\
\text { and compression }\end{array}$ & & 43.6 & & 342 & & 16 \\
\hline $\begin{array}{l}\text { Densified wood } \\
\text { film }\end{array}$ & $\begin{array}{l}\text { Chemical treatment } \\
\text { and compression }\end{array}$ & & & & 284.2 & & 17 \\
\hline $\begin{array}{c}\text { Densified wood } \\
\text { film }\end{array}$ & $\begin{array}{l}\text { Delignified via } \\
\text { ionic liquid } \\
\text { treatment and } \\
\text { pressing }\end{array}$ & 1.35 & 39 & & 430 & & 18 \\
\hline Densified wood & $\begin{array}{l}\text { Chemical treatment } \\
\text { and compression }\end{array}$ & 1.3 & & & 548 & 43.3 & 19 \\
\hline $\begin{array}{l}\text { Densified/cooling } \\
\text { wood }\end{array}$ & $\begin{array}{l}\text { Chemical treatment } \\
\text { and compression }\end{array}$ & 1.2 & & & 404.3 & & 20 \\
\hline Transparent wood & $\begin{array}{l}\text { Chemical treatment } \\
\text { and impregnation }\end{array}$ & 1.2 & 2.05 & & 90.1 & & 21 \\
\hline Transparent wood & $\begin{array}{l}\text { Chemical treatment } \\
\text { and impregnation }\end{array}$ & & 2.37 & 1.22 & 45.38 & 23.38 & 22 \\
\hline $\begin{array}{c}\text { Delignified } \\
\text { wood/phenol } \\
\text { formaldehyde }\end{array}$ & $\begin{array}{l}\text { Delignification, } \\
\text { impregnation and } \\
\text { compression }\end{array}$ & 1.4 & 62 & & 670 & & 23 \\
\hline $\begin{array}{l}\text { Wood/phenol } \\
\text { formaldehyde }\end{array}$ & $\begin{array}{l}\text { Impregnation and } \\
\text { compression }\end{array}$ & 1.1 & 22 & & 250 & & 24 \\
\hline $\begin{array}{l}\text { Delignified and } \\
\text { densified wood }\end{array}$ & $\begin{array}{c}\text { Delignified and } \\
\text { densified }\end{array}$ & 1.15 & 35 & & 270 & & 25 \\
\hline $\begin{array}{c}\text { Transparent film } \\
\text { (Balsa wood) }\end{array}$ & $\begin{array}{l}\mathrm{NaClO} \text { treatment } \\
\text { and pressing }\end{array}$ & 1.2 & 38.3 & & 378.4 & & $\begin{array}{l}\text { This work, } \\
\text { Figure S11 }\end{array}$ \\
\hline
\end{tabular}




\begin{tabular}{|c|c|c|c|c|c|c|c|}
\hline $\begin{array}{c}\text { Copy paper } \\
\text { (general) }\end{array}$ & Randomly & 1.1 & 1.66 & & 18.2 & This work, \\
distributed & & & & & Figure 3a \\
\hline
\end{tabular}

“\|”: parallel to fiber growth direction; " $\perp$ ": perpendicular to fiber direction
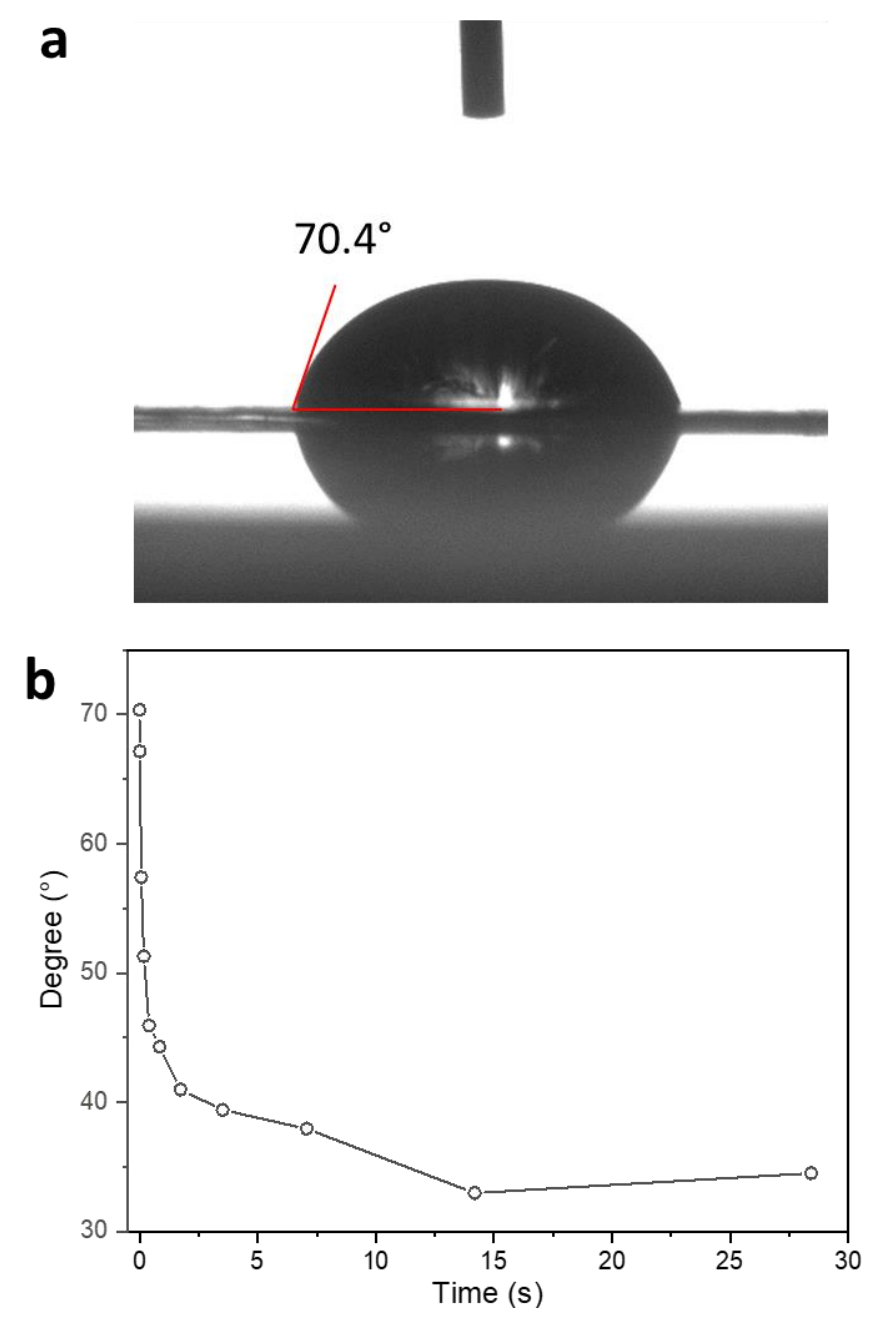

Figure S12. Water contact angle and dynamic water absorption of TWF. The initial water contact angle was $70.4^{\circ}$ and decreased to $36^{\circ}$ after 27 seconds, this phenomenon is due to the water absorption and hydrophilic nature of cellulose and hemicelluloses. 

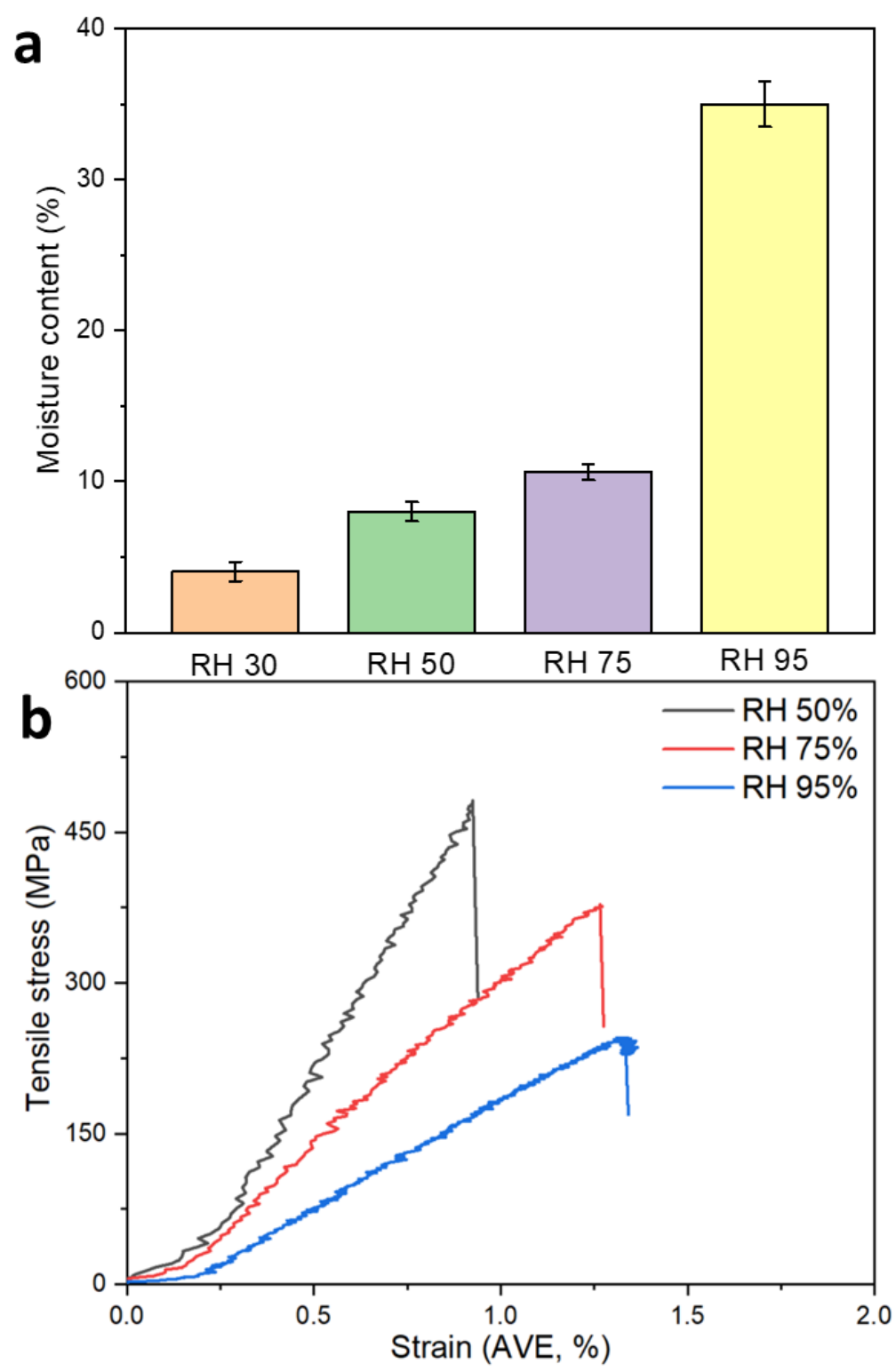

Figure S13. Moisture content and TWF tensile test at different relative humidity (RH). 
Table S3. Comparison of the mechanical properties of the traditional engineering materials, natural fibers, petroleum-based polymers, metals, alloys, bio-based and synthetic fiber materials.

\begin{tabular}{|c|c|c|c|c|c|c|}
\hline \multirow[t]{2}{*}{ Material } & \multirow{2}{*}{$\begin{array}{l}\text { Density }(\mathrm{g} \\
\left.\mathrm{cm}^{-3}\right)\end{array}$} & \multicolumn{2}{|c|}{ Young's modulus $E$} & \multicolumn{2}{|c|}{ Strength $\sigma$} & \multirow[t]{2}{*}{ Ref. } \\
\hline & & $E(\mathrm{GPa})$ & $\begin{array}{c}\text { Specific } E(\mathrm{GPa} \\
\left.\mathrm{cm}^{3} \mathrm{~g}^{-1}\right)\end{array}$ & $\sigma(\mathrm{MPa})$ & $\begin{array}{c}\text { Specific } \sigma \\
\left(\mathrm{MPa} \mathrm{cm}^{3} \mathrm{~g}^{-1}\right)\end{array}$ & \\
\hline \multicolumn{6}{|c|}{ Natural fibers } & \\
\hline $\begin{array}{l}\text { Transparent } \\
\text { wood film }\end{array}$ & 1.2 & $\begin{array}{r}49.9 \\
\pm 10.8\end{array}$ & $41.6 \pm 9$ & $\begin{array}{r}469.9 \\
\pm 114.3\end{array}$ & $391.6 \pm 95.2$ & $\begin{array}{l}\text { This } \\
\text { work }\end{array}$ \\
\hline Cotton & $1.5-1.6$ & $5.5-12.6$ & $3.5-8.2$ & $281-597$ & $181.3-385.2$ & \multirow{5}{*}{26} \\
\hline Jute & 1.3 & 26.5 & 20.4 & $393-773$ & $302.3-594.6$ & \\
\hline Sisal & 1.5 & $9.4-22$ & $6.3-14.7$ & $411-635$ & $274-423.3$ & \\
\hline Coir & 1.2 & $4-6$ & $3.3-5$ & $175-220$ & $145.8-183.3$ & \\
\hline Ramie & 1.5 & 61.4 & 40.9 & 400 & 266.7 & \\
\hline Hemp & 1.48 & 70 & 47.3 & 690 & 466.2 & 27 \\
\hline Pineapple & 1.56 & 62 & 39.7 & 170 & 109 & 28 \\
\hline \multicolumn{6}{|c|}{ Synthetic fibers, polymers and plastics } & \\
\hline E-glass & 2.5 & 70 & 28 & $\begin{array}{l}2000- \\
3500\end{array}$ & $800-1400$ & \multirow{3}{*}{29} \\
\hline S-glass & 2.5 & 86 & 34.4 & 4570 & 1828 & \\
\hline Aramide & 1.4 & $63-67$ & $45-47.9$ & $\begin{array}{l}3000- \\
3150\end{array}$ & $2142.8-2250$ & \\
\hline PET & 1.34 & 2.3 & 1.7 & 55 & 41 & \multirow{6}{*}{30} \\
\hline Nylon-6 & 1.1 & 2.14 & 2 & 47 & 42.7 & \\
\hline $\mathrm{ABS}$ & 1.1 & 2.1 & 1.9 & 34 & 30.9 & \\
\hline PVC & 1.39 & 3.1 & 2.3 & 58 & 41.7 & \\
\hline Polyamide-6 & 1.13 & 1 & 0.9 & 40 & 35.4 & \\
\hline Polycarbonate & 1.2 & 2.1 & 1.75 & 50 & 41.7 & \\
\hline
\end{tabular}




\begin{tabular}{|c|c|c|c|c|c|c|}
\hline Polyarylate & 1.2 & 2.2 & 1.8 & 68 & 56.7 & \multirow{6}{*}{30} \\
\hline Polyester & 1.39 & 9 & 6.5 & 40 & 28.8 & \\
\hline Bisphenol & 1.2 & 16 & 13.3 & 280 & 233.3 & \\
\hline PP & 0.9 & 2 & 2.2 & 26 & 28.9 & \\
\hline HDPE & 0.95 & 1.25 & 1.3 & 32 & 33.7 & \\
\hline $\begin{array}{c}\text { Polystyrene } \\
\text { (general) }\end{array}$ & 1.05 & 2.1 & 2 & 42 & 40 & \\
\hline \multicolumn{6}{|c|}{ Metals, steels and alloys } & \\
\hline Stainless steel & 7.92 & 220 & 27.8 & 525 & 66.3 & \\
\hline $\begin{array}{c}\text { 4Ni-Cr-Mo } \\
\text { steel }\end{array}$ & 7.83 & 225 & 28.7 & 1550 & 198 & 31 \\
\hline Steel & 7.8 & 210 & 26.9 & 4100 & 525.6 & 32 \\
\hline $\begin{array}{l}\text { Fe-6.38Ti- } \\
\text { 2.4B steel }\end{array}$ & 7.4 & 236 & 31.9 & 900 & 121.6 & 33 \\
\hline Grey cast iron & 7.39 & 150 & 20.3 & 300 & 40.5 & \multirow{3}{*}{31} \\
\hline Aluminium & 2.75 & 70 & 25.9 & 60 & 21.8 & \\
\hline Copper & 8.97 & 130 & 14.5 & 216 & 24.1 & \\
\hline $\begin{array}{c}\mathrm{Al} \text { alloy } \\
\text { (2000 Series) }\end{array}$ & 2.78 & & & 496 & 178.5 & 34 \\
\hline $\begin{array}{c}\text { 4Sn-4Al- } \\
\text { 4Mo-0.5Si } \\
\text { alloy }\end{array}$ & 4.5 & 150 & 33.3 & 1390 & 309 & 31 \\
\hline $\begin{array}{l}\text { Cr-Mn-Fe- } \\
\text { Co-Ni alloy }\end{array}$ & 8.01 & 214.5 & 26.8 & 1280 & 159.8 & 35 \\
\hline $\begin{array}{c}\text { Ti6Al4V } \\
\text { alloy }\end{array}$ & 4.42 & 114 & 25.8 & 897 & 203 & 36 \\
\hline $\begin{array}{c}\text { Mg-6Al-1Zn } \\
\text { alloy }\end{array}$ & 1.8 & 48 & 26.7 & 300 & 167 & 31 \\
\hline
\end{tabular}




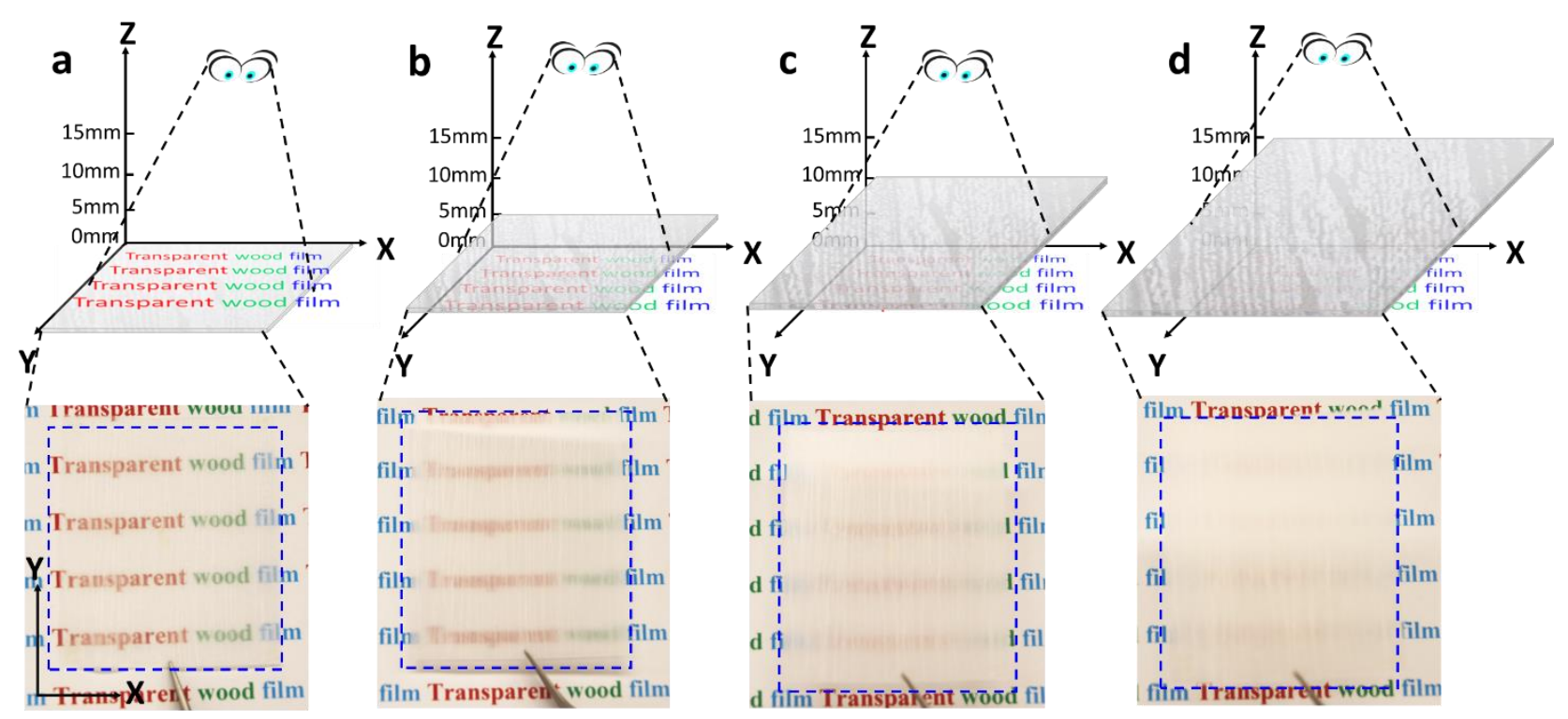

Figure S14. Optical haze, clarity and light scattering of TWF. The TWF is placed (a) directly on the paper printed text "transparent wood film", (b) $5 \mathrm{~mm}$, (c) $10 \mathrm{~mm}$ and (d) $15 \mathrm{~mm}$ above the text paper, respectively. (a) The text is clear when TWF is touching the paper surface. The text starts getting blurred when TWF is place $5 \mathrm{~mm}$ above the paper due to light scattering. There is very limited clarity when the TWF is placed $10 \mathrm{~mm}$ above the text, and completely unreadable when positioned $15 \mathrm{~mm}$ above. This demonstrates the material high haziness. 

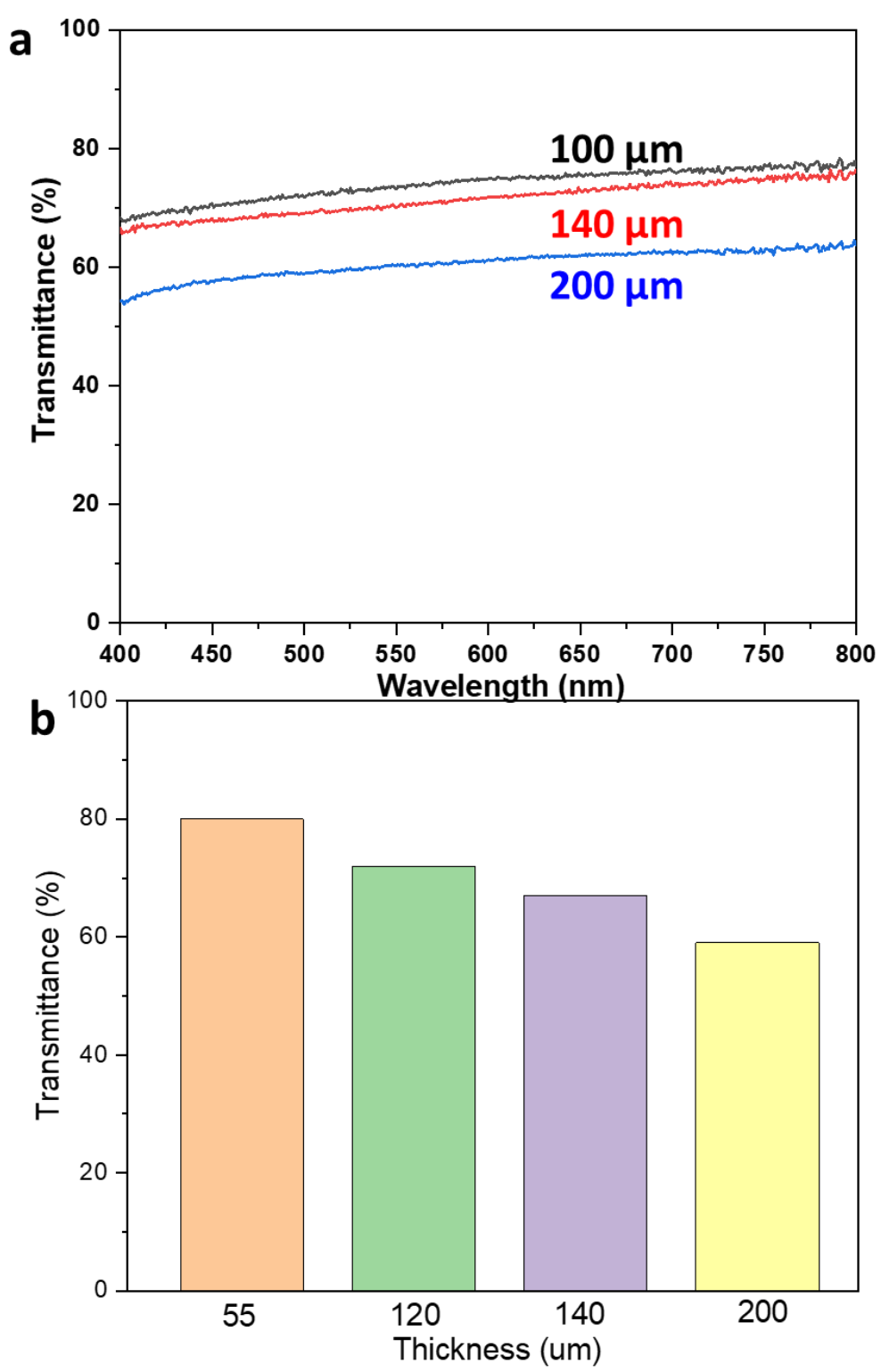

Figure S15. Optical transmittance spectra obtained with various TWF thicknesses $(100 \mu \mathrm{m}, 140$ $\mu \mathrm{m}$ and $200 \mu \mathrm{m})$. 

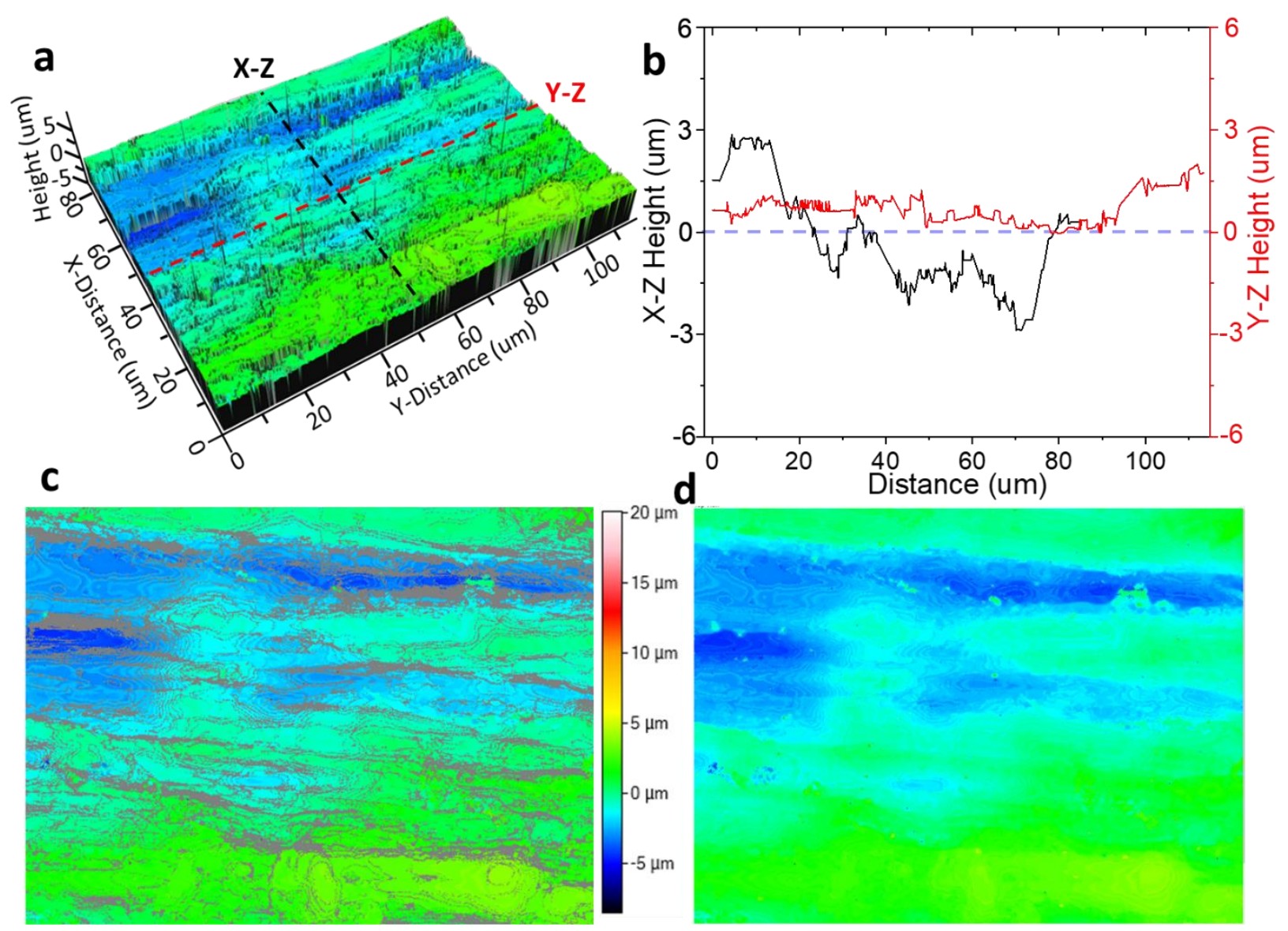

Figure S16. Surface roughness and 3D profile of TWF. (a) 3D structure of TWF surface. (b) The variation surface roughness along scanning by $\mathrm{x}-\mathrm{y}$ planes. The surface roughness varies around 3 $\mu \mathrm{m}$ in the z-direction. (c) 2D surface roughness distribution. (d) The grey areas in "c" are smoothen using "Fill In Invalids" model. 

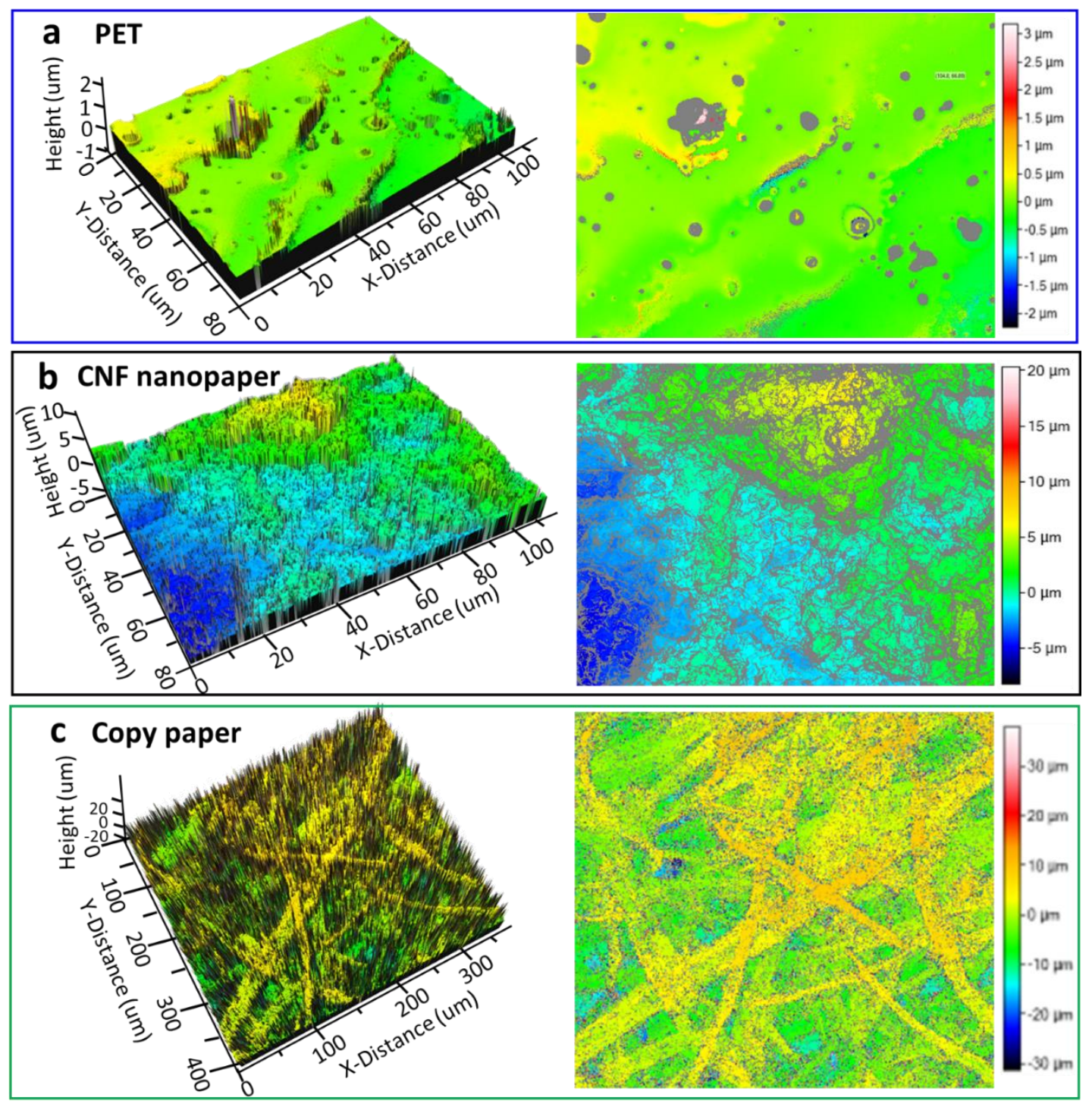

Figure S17. Surface roughness and 3D profile of (a) PET, (b) CNF nanopaper and (c) copy paper, respectively.

Surface roughness is a crucial parameter for an electronic substrate. Although TWF has slightly higher surface roughness than PET (Figures S16a and S17a), LCF ink exhibits a better adhesion on the hydrophilic TWF than on the hydrophobic PET substrate. Compared to CNF nanopaper and copy paper, TWF has a lower surface roughness than both materials (Figures S16 and S17bc). Surface roughness is an important parameter when printing or coating conductive ink on an electronics substrate. 


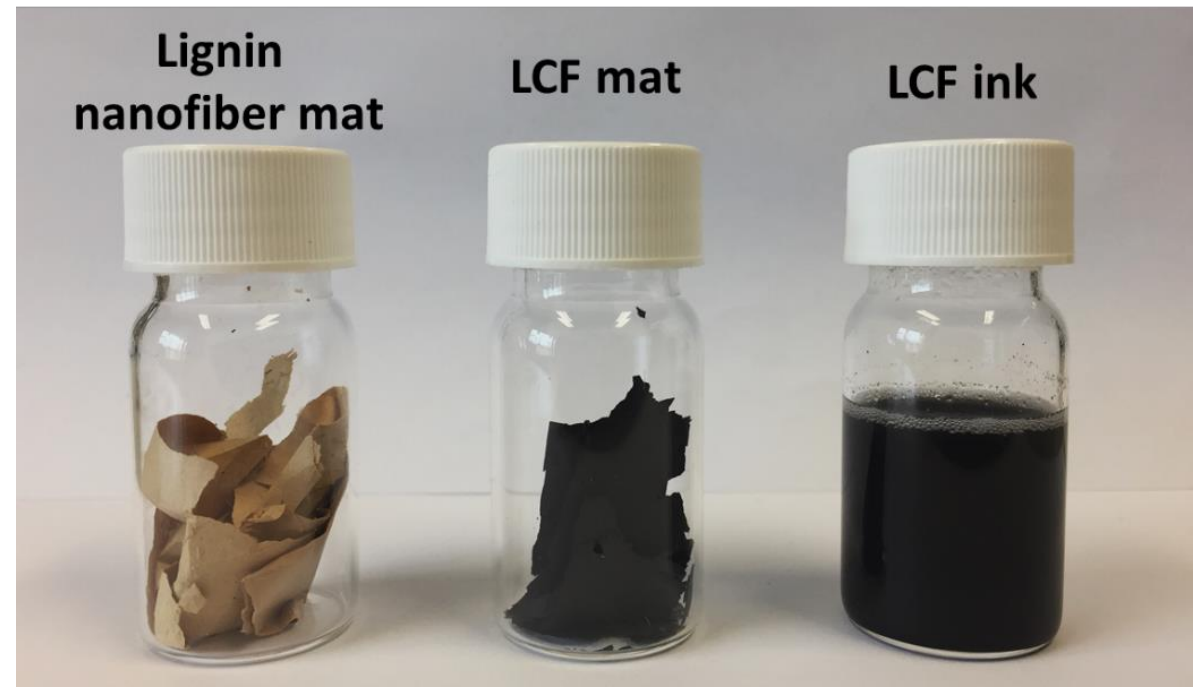

Figure S18. Photograph of lignin nanofiber mat, LCF mat and ink, respectively. 

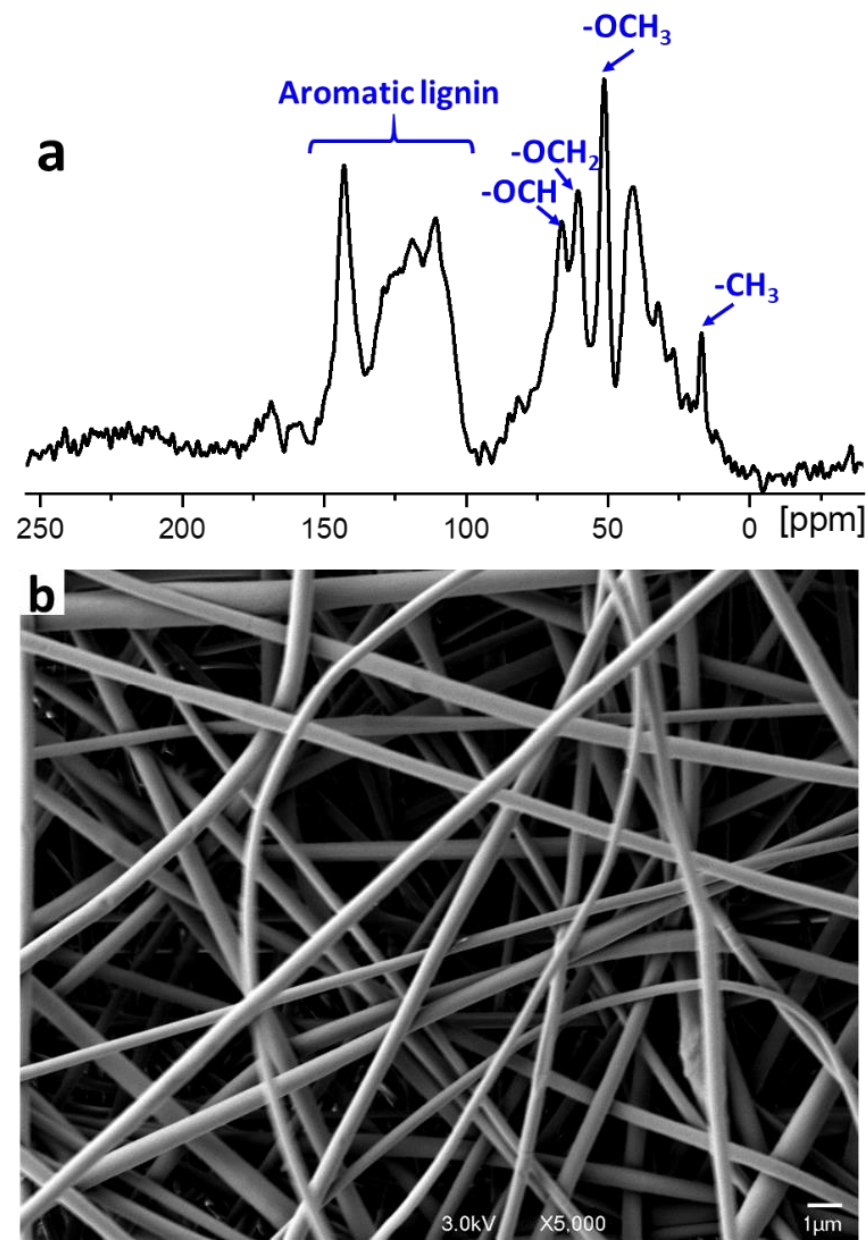

Figure S19. (a) Solid state ${ }^{13} \mathrm{C}$ NMR spectrum and (b) SEM image of the electrospun lignin fibers.

Typical peaks at $51.5 \mathrm{ppm}$ and $111-143 \mathrm{ppm}$ attributed to methoxy $\left(-\mathrm{OCH}_{3}\right)$ group and aromatic group of lignin, respectively; SEM image shows that the diameter of as-spun lignin fibers can be up to $0.2-1 \mu \mathrm{m}$. 

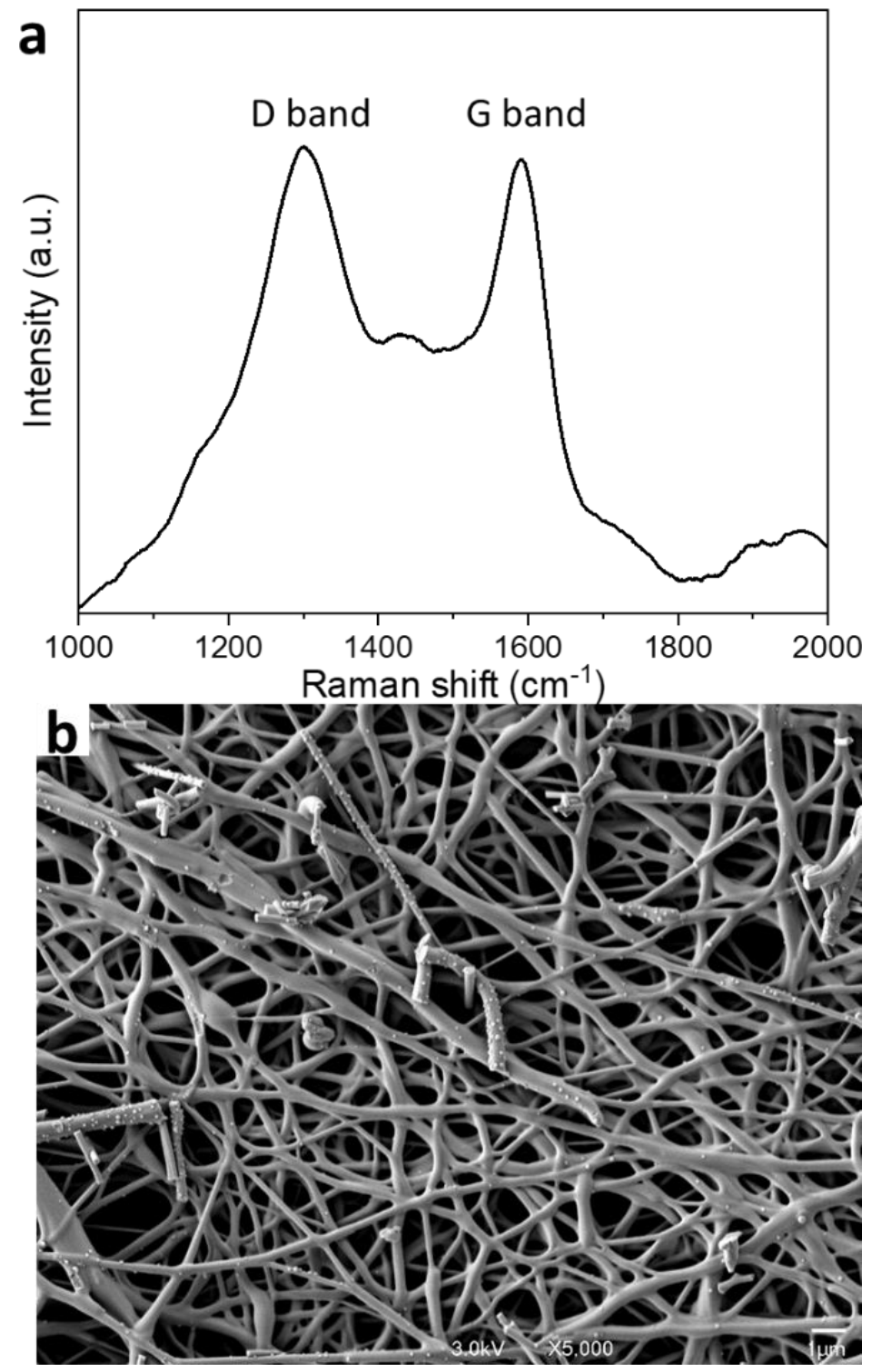

Figure S20. (a) Raman spectrum and (b) SEM image of the LCF.

Raman spectra possess two major bands at 1301 and $1585 \mathrm{~cm}^{-1}$ corresponding to D- and Gbands, respectively. The intensity ratio of D-band and G-band (ID/IG) is 1.3 , it is consistent with the expected value for LCF. ${ }^{37}$ SEM image shows interconnected fiber network structures with an average fiber diameter of $250 \mathrm{~nm}$. 

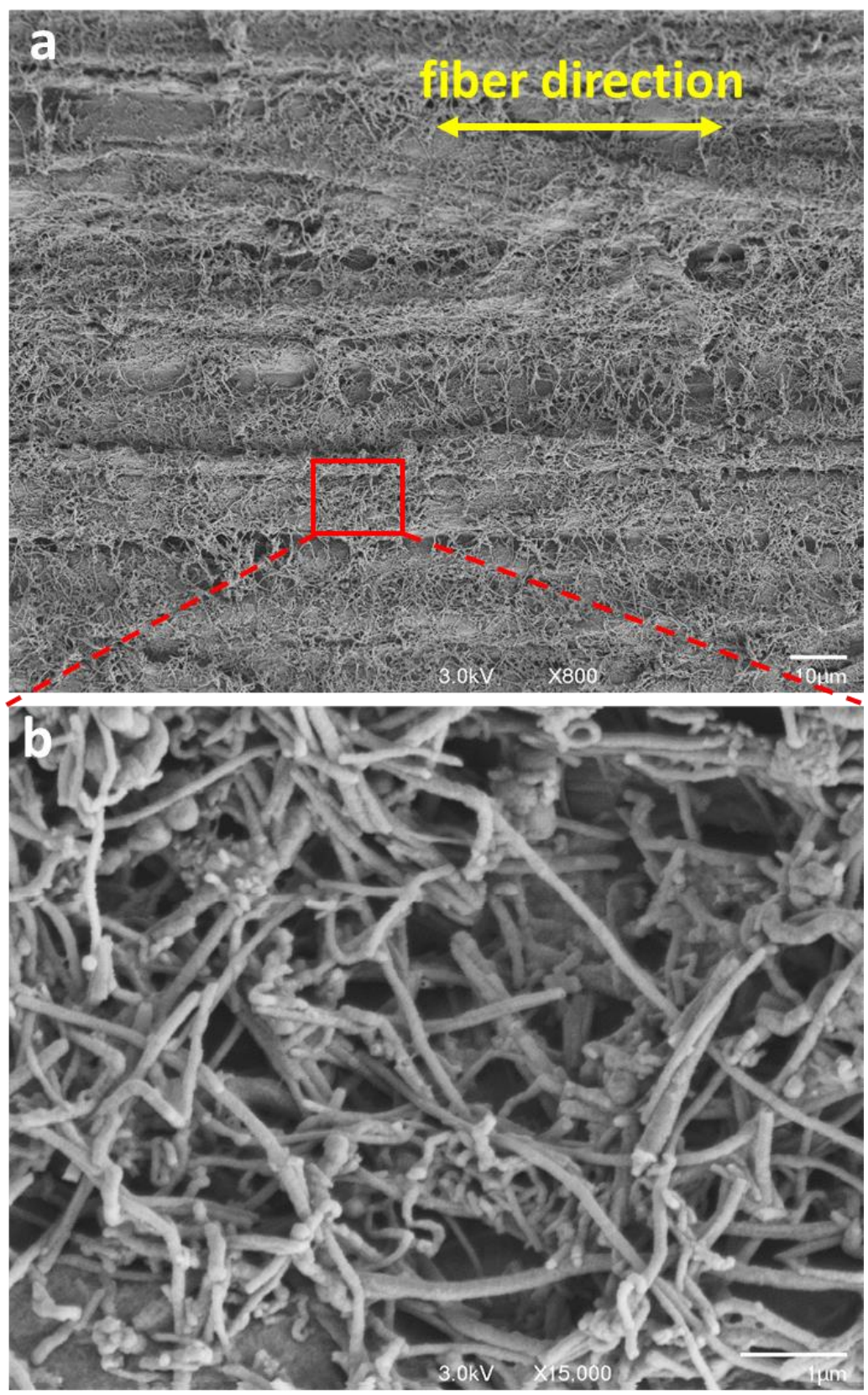

Figure S21. LCF ink printed on TWF surface. (a) The LCF ink is homogeneously distributed on the surface of TWF. (b) Nano-scale carbon fibers have random interconnect with a favorable network to the transportation of electrons. 


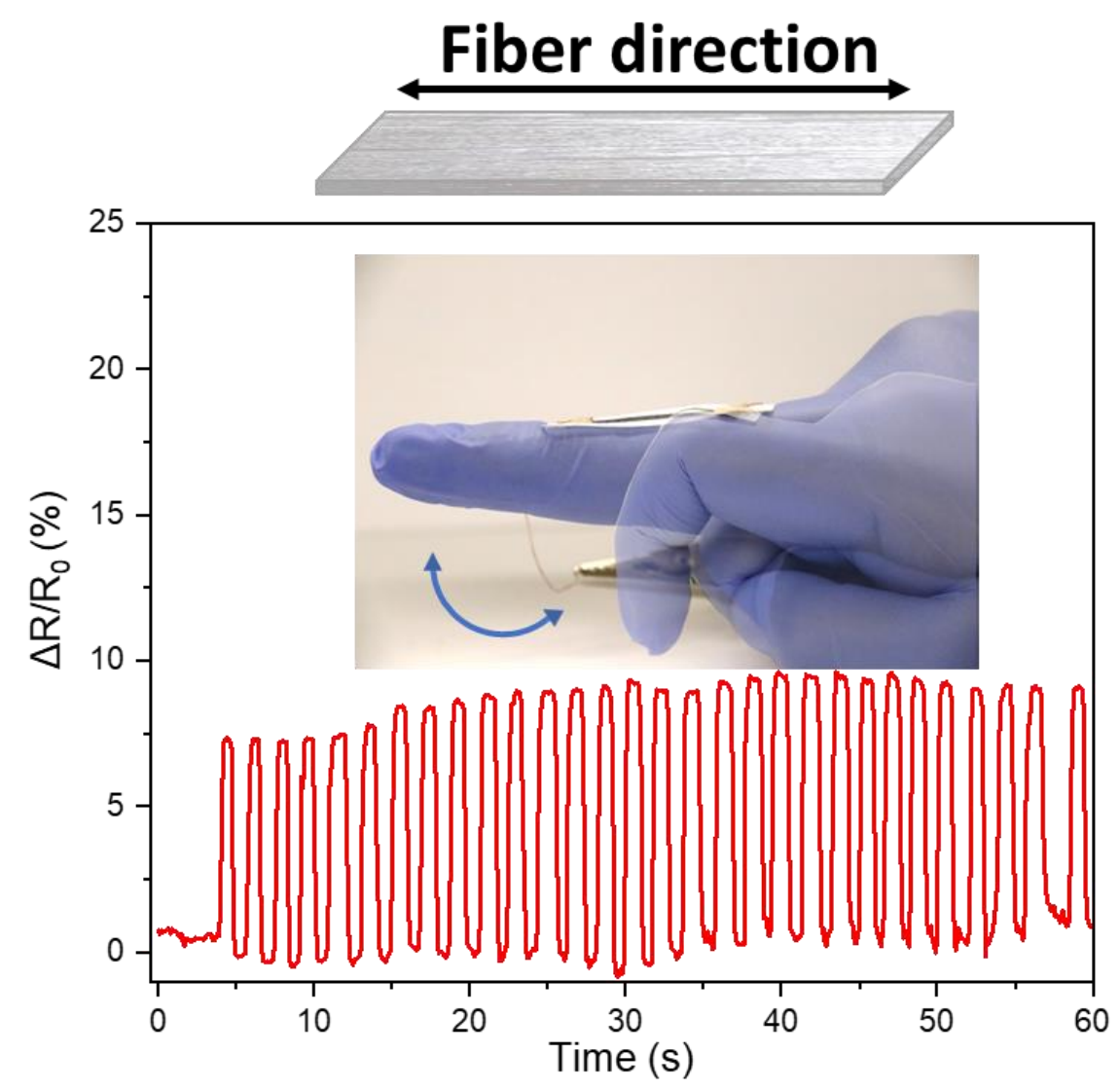

Figure S22. Flexible strain sensor demonstration in the TWF's fiber growth direction (longitudinal). Normalised relative resistance variation as a function of time. 

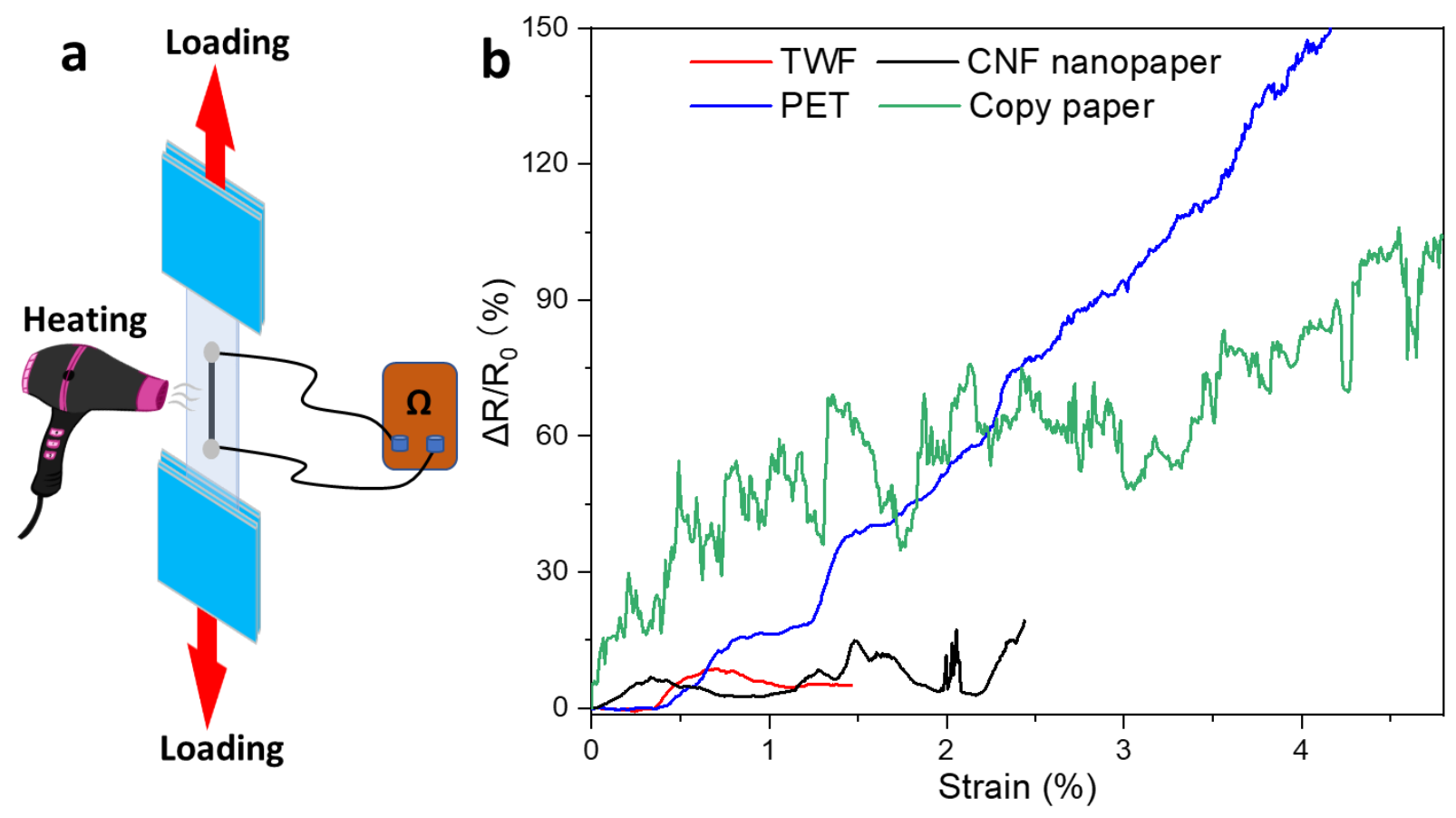

Figure S23. Thermo-mechanical and electrical stability performances of the flexible strain sensor printed LCF ink on different substrates. (a) Schematic of the experimental design. (b) Normalised relative resistance variation as a function of tensile strain. The sample was heated up to $\approx 90{ }^{\circ} \mathrm{C}$ when the data were collected. 

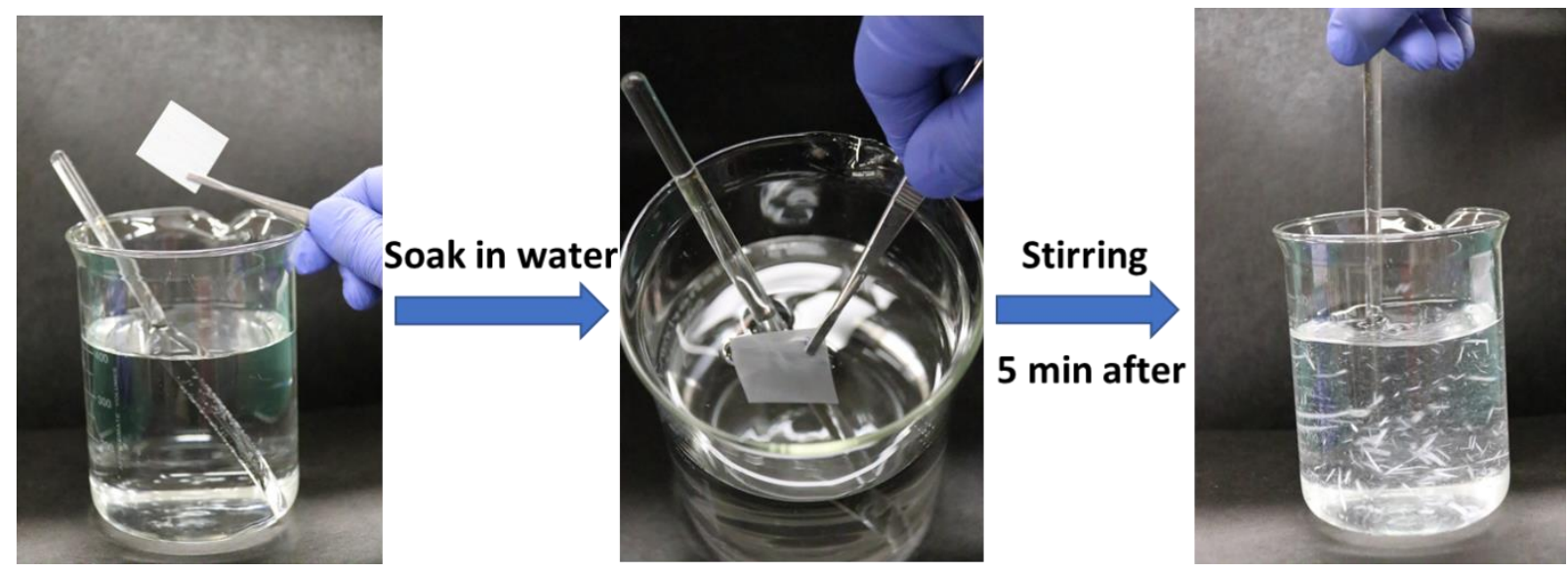

Figure S24. Potential TWF recycling. Upon soaking in a water bath with mechanical agitation, the TWF substrate is dislocated into cellulose fiber bundles. This support that the biodegradable substrate has recyclable characteristics. 
Table S4. Summary of the differences between current work and other published references.

\begin{tabular}{|c|c|c|c|c|c|c|c|c|c|c|c|c|}
\hline Materials & $\begin{array}{l}\text { Delig } \\
\text { nified }\end{array}$ & $\begin{array}{l}\text { Removal } \\
\text { of hemi. }\end{array}$ & $\begin{array}{l}\text { Stre } \\
\text { ngth }\end{array}$ & $\begin{array}{l}\text { Transp } \\
\text { arent }\end{array}$ & $\begin{array}{c}\text { Flexi } \\
\text { ble }\end{array}$ & $\begin{array}{l}\text { Impreg. } \\
\text { polymer }\end{array}$ & $\begin{array}{l}\text { Cellulose } \\
\text { alignment }\end{array}$ & $\begin{array}{l}\text { Simple } \\
\text { process }\end{array}$ & $\begin{array}{l}\text { Large } \\
\text { scale }\end{array}$ & $\begin{array}{l}\text { Bio- } \\
\text { based }\end{array}$ & $\begin{array}{l}\text { Printed } \\
\text { green ink }\end{array}$ & Ref. \\
\hline $\begin{array}{c}\text { TWF - LCF } \\
\text { ink } \\
\text { electronics }\end{array}$ & $\sqrt{ }$ & $\sqrt{ }$ & H & $\sqrt{ }$ & $\sqrt{ }$ & $x$ & $\sqrt{ }$ & $\sqrt{ }$ & $\sqrt{ }$ & $\sqrt{ }$ & $\sqrt{ }$ & $\begin{array}{l}\text { This } \\
\text { work }\end{array}$ \\
\hline TW & $\sqrt{ }$ & $x$ & $\mathrm{~L}$ & $\sqrt{ }$ & $x$ & $\sqrt{ }$ & $\sqrt{ }$ & $\sqrt{ }$ & $\sqrt{ }$ & $x$ & $x$ & $\begin{array}{l}21,22, \\
38,39\end{array}$ \\
\hline $\begin{array}{c}\mathrm{CNF} \\
\text { nanopaper }\end{array}$ & $\sqrt{ }$ & $\sqrt{ }$ & $\mathrm{M}$ & $\sqrt{ }$ & $\sqrt{ }$ & $x$ & $x$ & $x$ & $x$ & $\sqrt{ }$ & $x$ & $40-43$ \\
\hline $\begin{array}{l}\text { Cellulose wet- } \\
\text { stretching film }\end{array}$ & $\sqrt{ }$ & $\sqrt{ }$ & $\mathrm{M}$ & $\sqrt{ }$ & $\sqrt{ }$ & $x$ & $\sqrt{ }$ & $x$ & $x$ & $\sqrt{ }$ & $x$ & $9-12$ \\
\hline CNF ribbon & $\sqrt{ }$ & $\sqrt{ }$ & $\mathrm{H}$ & $\sqrt{ }$ & $\sqrt{ }$ & $\sqrt{ }$ & $\sqrt{ }$ & $x$ & $x$ & $\sqrt{ }$ & $x$ & 6 \\
\hline CNF filament & $\sqrt{ }$ & $\sqrt{ }$ & $\mathrm{H}$ & $x$ & $\sqrt{ }$ & $x$ & $\sqrt{ }$ & $x$ & $x$ & $\sqrt{ }$ & $x$ & 14,15 \\
\hline $\begin{array}{l}\text { Aligned } \\
\text { Cellulose }\end{array}$ & $\sqrt{ }$ & $\sqrt{ }$ & M & $\sqrt{ }$ & $\sqrt{ }$ & $x$ & $\sqrt{ }$ & $x$ & $x$ & $\sqrt{ }$ & $x$ & $\begin{array}{r}3,13,4 \\
4,45\end{array}$ \\
\hline $\begin{array}{l}\text { Densified and } \\
\text { delignified } \\
\text { wood }\end{array}$ & $\sqrt{ }$ & $\sqrt{ }$ & $\bar{M}$ & $x$ & $x$ & $x$ & $\sqrt{ }$ & $\sqrt{ }$ & $\sqrt{ }$ & $\sqrt{ }$ & $x$ & 19,20 \\
\hline $\begin{array}{c}\text { Cellulose bulk } \\
\text { material }\end{array}$ & $\sqrt{ }$ & $x$ & $\mathrm{M}$ & $x$ & $x$ & $x$ & $\sqrt{ }$ & $\sqrt{ }$ & $\sqrt{ }$ & $\sqrt{ }$ & $x$ & 25,46 \\
\hline Wood comp. & $\sqrt{ }$ & $x$ & $\mathrm{M}$ & $x$ & $x$ & $\sqrt{ }$ & $\sqrt{ }$ & $\sqrt{ }$ & $\sqrt{ }$ & $x$ & $x$ & $\begin{array}{l}23,24, \\
47-49\end{array}$ \\
\hline $\begin{array}{l}\text { Delignified } \\
\text { wood/epoxy }\end{array}$ & $\sqrt{ }$ & $x$ & $\mathrm{H}$ & $x$ & $x$ & $\sqrt{ }$ & $\sqrt{ }$ & $\sqrt{ }$ & $\sqrt{ }$ & $x$ & $x$ & 50 \\
\hline Flexible wood & $\sqrt{ }$ & $x$ & $\mathrm{~L}$ & $x$ & $\sqrt{ }$ & $x$ & $x$ & $\sqrt{ }$ & $\sqrt{ }$ & $\sqrt{ }$ & $x$ & 51 \\
\hline
\end{tabular}

TWF: transparent wood film; TW: transparent wood; CNF: cellulose nanofiber; $\sqrt{ }$ : Yes; $\times$ : No; H:

high; M: medium; L: low

Most of previous publications on transparent wood performed a petroleum-based polymer impregnation step, they are therefore not bio-based. The CNF nanopapers and wet-stretch films have relatively low mechanical properties. CNF nanopapers, filament and ribbon, wet stretch films and aligned cellulose materials follow complex processes and are therefore difficult to 
scale-up. The densified woods, cellulose bulk materials and wood composites have a medium tensile strength, and they are neither transparent nor flexible, thus not suitable for flexible electronic purposes. The flexible wood is not transparent with low mechanical properties. Our material combines a fully wood-based substrate with a bio-based conductive ink, making it the only fully bio-based, wood derived electronic circuit.

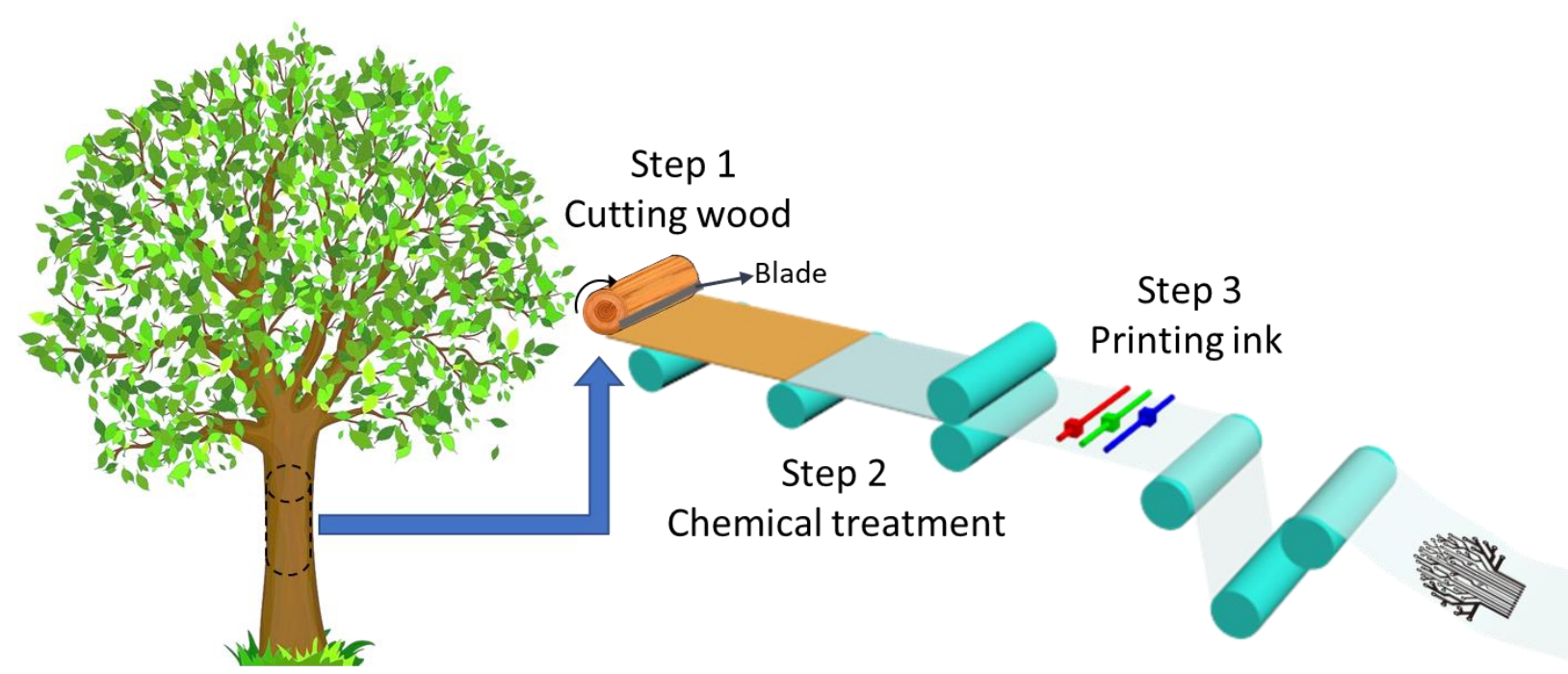

Figure S25. Schematic of envisioned large-scale and continuous fabrication of the TWF for flexible electronics via roll-to-roll processing system. 


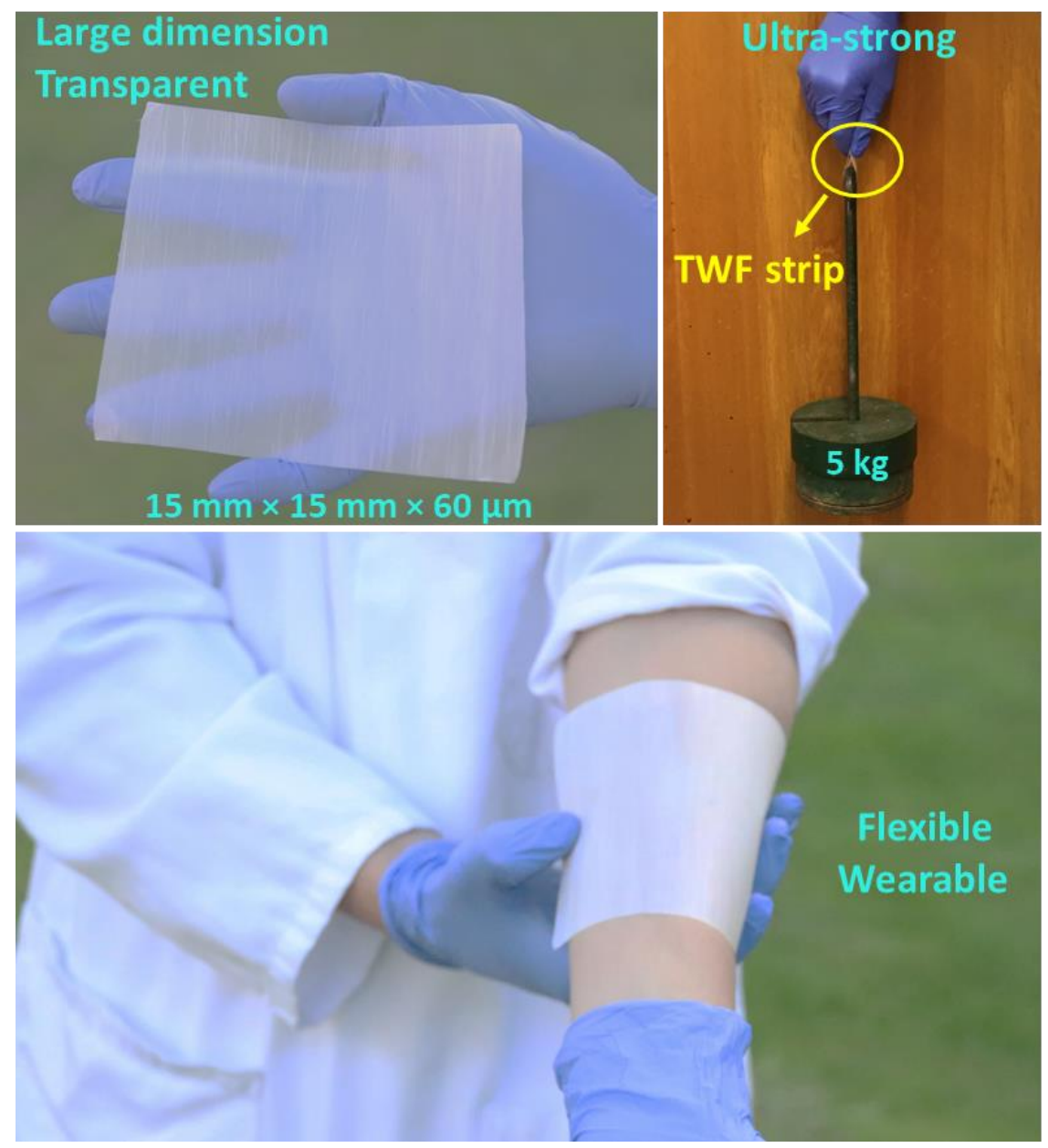

Figure S26. The strong, flexible and transparent wood film with large-scale dimension of $15 \mathrm{~cm}$ (length) $\times 15 \mathrm{~cm}($ width $) \times 60 \mu \mathrm{m}$ (thickness), demonstrates the possibility to manufacture largescale TWF. A $5 \mathrm{~kg}$ weight is lifted with a TWF strip $(100 \mathrm{~mm} \times 10 \mathrm{~mm} \times 60 \mu \mathrm{m})$. The flexible TWF is also wearable on human skin. 


\section{Process cost calculation of producing the wood-based flexible electronics}

A balsa veneer with dimension of $150 \mathrm{~mm} \times 100 \mathrm{~mm} \times 1 \mathrm{~mm}$ is supplied at $1.5 \mathrm{US} \$$. The cost of the wood veneer is around 10 US $\$ / \mathrm{m}^{2}$. Sodium chlorite and sodium hydroxide are supplied at the price of 10-30 US $\$ / \mathrm{kg}$ and 1-2 US $\$ / \mathrm{kg}$, respectively. At the current lab scale production, the ink cost is around 2000 US $\$ / \mathrm{kg}$. Around $90 \%$ of the ink cost is labour related production. In a commercial large-scale production, we predict that the cost of this ink would fall below 200 US $\$ / \mathrm{kg}$. The total cost of wood-based flexible electronics used for production of one square meter of electronics is based on our chemical treatment and printing processes as listed in Table S5. According to our estimation at lab scale, the overall material cost is around $52.6 \mathrm{US} \$ / \mathrm{m}^{2}$ for production of the electronics. It should be noted that the commercial production cost would be lower than our lab-scale production cost.

Table S5. Cost estimation of producing the wood-based flexible electronics.

\begin{tabular}{|c|c|c|c|c|}
\hline Material/Chemical & Price (US \$) & Concentration & Consumption & Cost (US \$) \\
\hline Wood (retail) & $10 \$ / \mathrm{m}^{2}$ & & $1 \mathrm{~m}^{2}$ & $10 \$$ \\
\hline $\mathrm{NaClO}_{2}$ & $20 \$ / \mathrm{kg}$ & 1 wt. $\%$ & $10 \mathrm{~L}$ & $2 \$$ \\
\hline $\mathrm{NaOH}$ & $1.5 \$ / \mathrm{kg}$ & $4 \mathrm{wt.} \%$ & $10 \mathrm{~L}$ & $0.6 \$$ \\
\hline Ink (lab scale) & $2000 \$ / \mathrm{kg}$ & $10 \mathrm{wt} \%$ & $0.2 \mathrm{~L}$ & $40 \$$ \\
\hline Electronics & & & & $52.6 \$ / \mathrm{m}^{2}$ \\
\hline lab scale total cost) & & & & \\
\hline
\end{tabular}




\section{References}

(1) Gibson, L. J.; Ashby, M. F. Cellular Solids: Structure and Properties; Cambridge University Press: Cambridge, 1999.

(2) Rafsanjani, A.; Stiefel, M.; Jefimovs, K.; Mokso, R.; Derome, D.; Carmeliet, J. Hygroscopic Swelling and Shrinkage of Latewood Cell Wall Micropillars Reveal Ultrastructural Anisotropy. J. R. Soc. Interface 2014, 11, 20140126.

(3) Zhu, M.; Wang, Y.; Zhu, S.; Xu, L.; Jia, C.; Dai, J.; Song, J.; Yao, Y.; Wang, Y.; Li, Y.; Henderson, D.; Luo, W.; Li, H.; Minus, M.L.; Li, T.; Hu, L. Anisotropic, Transparent Films with Aligned Cellulose Nanofibers. Adv. Mater. 2017, 29, 1606284.

(4) Borrega, M.; Ahvenainen, P.; Serimaa, R.; Gibson, L. Composition and Structure of Balsa (Ochroma Pyramidale) Wood. Wood Sci. Technol. 2015, 49, 403-420.

(5) Ansari, F.; Galland, S.; Johansson, M.; Plummer, C. J. G.; Berglund, L. A. Cellulose Nanofiber Network for Moisture Stable, Strong and Ductile Biocomposites and Increased Epoxy Curing Rate. Compossites, Part A 2014, 63, 35-44.

(6) Tang, H.; Butchosa, N.; Zhou, Q. A Transparent, Hazy, and Strong Macroscopic Ribbon of Oriented Cellulose Nanofibrils Bearing Poly(Ethylene Glycol). Adv. Mater. 2015, 27, 2070-2076.

(7) Yang, X.; Berglund, L. A. Water-Based Approach to High-Strength All-Cellulose Material with Optical Transparency. ACS Sustain. Chem. Eng. 2018, 6, 501-510.

(8) Yang, X.; Berthold, F.; Berglund, L. A. High-Density Molded Cellulose Fibers and Transparent Biocomposites Based on Oriented Holocellulose. ACS Appl. Mater. Interfaces 2019, 11, 10310-10319.

(9) Wang, B.; Torres-Rendon, J. G.; Yu, J.; Zhang, Y.; Walther, A. Aligned Bioinspired Cellulose Nanocrystal-Based Nanocomposites with Synergetic Mechanical Properties and Improved Hygromechanical Performance. ACS Appl. Mater. Interfaces 2015, 7, 45954607. 
(10) Torres-Rendon, J. G.; Schacher, F. H.; Ifuku, S.; Walther, A. Mechanical Performance of Macrofibers of Cellulose and Chitin Nanofibrils Aligned by Wet-Stretching: A Critical Comparison. Biomacromolecules 2014, 15, 2709-2717.

(11) Sehaqui, H.; Ezekiel Mushi, N.; Morimune, S.; Salajkova, M.; Nishino, T.; Berglund, L. A. Cellulose Nanofiber Orientation in Nanopaper and Nanocomposites by Cold Drawing. ACS Appl. Mater. Interfaces 2012, 4, 1043-1049.

(12) Yao, J.; Chen, S.; Chen, Y.; Wang, B.; Pei, Q.; Wang, H. Macrofibers with High Mechanical Performance Based on Aligned Bacterial Cellulose Nanofibers. ACS Appl. Mater. Interfaces 2017, 9, 20330-20339.

(13) Wang, S.; Jiang, F.; Xu, X.; Kuang, Y.; Fu, K.; Hitz, E.; Hu, L. Super-Strong, Super-Stiff Macrofibers with Aligned, Long Bacterial Cellulose Nanofibers. Adv. Mater. 2017, 29, 1702498.

(14) Håkansson, K. M. O.; Fall, A. B.; Lundell, F.; Yu, S.; Krywka, C.; Roth, S. V.; Santoro, G.; Kvick, M.; Prahl Wittberg, L.; Wågberg, L.; Söderberg, D. Hydrodynamic Alignment and Assembly of Nanofibrils Resulting in Strong Cellulose Filaments. Nat. Commun. 2014, 5, 4018 .

(15) Mittal, N.; Ansari, F.; Gowda Krishne, V.; Brouzet, C.; Chen, P.; Larsson, P. T.; Roth, S. V.; Lundell, F.; Wågberg, L.; Kotov, N. A.; Wågberg, L.; Söderberg, D. Multiscale Control of Nanocellulose Assembly: Transferring Remarkable Nanoscale Fibril Mechanics to Macroscale Fibers. ACS Nano 2018, 12, 6378-6388.

(16) Gan, W.; Chen, C.; Kim, H.-T.; Lin, Z.; Dai, J.; Dong, Z.; Zhou, Z.; Ping, W.; He, S.; Xiao, S.; Yu, M.; Hu, L. Single-Digit-Micrometer Thickness Wood Speaker. Nat. Commun. 2019, 10, 5084.

(17) Luo, J.; Wang, Z.; Xu, L.; Wang, A. C.; Han, K.; Jiang, T.; Lai, Q.; Bai, Y.; Tang, W.; Fan, F. R.; Wang, Z.L. Flexible and Durable Wood-Based Triboelectric Nanogenerators for Self-Powered Sensing in Athletic Big Data Analytics. Nat. Commun. 2019, 10, 5147. 
(18) Khakalo, A.; Tanaka, A.; Korpela, A.; Hauru, L. K. J.; Orelma, H. All-Wood Composite Material by Partial Fiber Surface Dissolution with an Ionic Liquid. ACS Sustain. Chem. Eng. 2019, 7, 3195-3202.

(19) Song, J.; Chen, C.; Zhu, S.; Zhu, M.; Dai, J.; Ray, U.; Li, Y.; Kuang, Y.; Li, Y.; Quispe, N.; Yao, Y.; Gong, A.; Leiste, U.H.; Bruck, H.A.; Zhu, J.Y.; Vellore, A.; Li, H.; Minus, M.L.; Jia, Z.; Martini, A.; et al. Processing Bulk Natural Wood into a High-Performance Structural Material. Nature 2018, 554, 224-228.

(20) Li, T.; Zhai, Y.; He, S.; Gan, W.; Wei, Z.; Heidarinejad, M.; Dalgo, D.; Mi, R.; Zhao, X.; Song, J.; Dai, J.; Chen, C.; Aili, A.; Vellore, A.; Martini, A.; Yang, R.; Srebric, J.; Yin, X.; Hu, L. A Radiative Cooling Structural Material. Science 2019, 364, 760-763.

(21) Li, Y.; Fu, Q.; Yu, S.; Yan, M.; Berglund, L. Optically Transparent Wood from a Nanoporous Cellulosic Template: Combining Functional and Structural Performance. Biomacromolecules 2016, 17, 1358-1364.

(22) Zhu, M.; Song, J.; Li, T.; Gong, A.; Wang, Y.; Dai, J.; Yao, Y.; Luo, W.; Henderson, D.; Hu, L. Highly Anisotropic, Highly Transparent Wood Composites. Adv. Mater. 2016, 28, $5181-5187$.

(23) Yano, H. Potential Strength for Resin-Impregnated Compressed Wood. J. Mater. Sci. Lett. 2001, 20, 1127-1129.

(24) Shams, M. I.; Yano, H.; Endou, K. Compressive Deformation of Wood Impregnated with Low Molecular Weight Phenol Formaldehyde (PF) Resin I: Effects of Pressing Pressure and Pressure Holding. J. Wood Sci. 2004, 50, 337-342.

(25) Frey, M.; Biffi, G.; Adobes-Vidal, M.; Zirkelbach, M.; Wang, Y.; Tu, K.; Hirt, A. M.; Masania, K.; Burgert, I.; Keplinger, T. Tunable Wood by Reversible Interlocking and Bioinspired Mechanical Gradients. Adv. Sci. 2019, 6, 1802190.

(26) Li, X.; Tabil, L. G.; Panigrahi, S. Chemical Treatments of Natural Fiber for Use in Natural Fiber-Reinforced Composites: A Review. J. Polym. Environ. 2007, 15, 25-33. 
(27) Ugbolue, S. C. O. Structure/Property Relationships in Textile Fibres. Text. Prog. 1990, 20, 1-43.

(28) Saheb, D. N.; Jog, J. P. Natural Fiber Polymer Composites : A Review. J. Adv. Polym. Technol. 2015, 18, 351-363.

(29) Bledzik, A.; Gassan, J. Composites Reinforced with Cellulose Based Fibers. Prog. Polym. Sci. 1993, 24, 221-274.

(30) Crompton, T. R. Mechanical Properties of Polymers. In Physical Testing of Plastics; Smithers Rapra Technology Ltd.: Shropshire, 2012; pp 1-148.

(31) Sharma, C. P. Engineering Materials: Properties and Applications of Metals and Alloys; PHI Learning Pvt. Ltd.: Delhi, 2003.

(32) Nickel, I.C. Properties of Some Metals and Alloys; International Nickel Company: New York, 1982.

(33) Springer, H.; Baron, C.; Szczepaniak, A.; Uhlenwinkel, V.; Raabe, D. Stiff, Light, Strong and Ductile: Nano-Structured High Modulus Steel. Sci. Rep. 2017, 7, 17-22.

(34) Dursun, T.; Soutis, C. Recent Developments in Advanced Aircraft Aluminium Alloys. Mater. Des. 2014, 56, 862-871.

(35) Gludovatz, B.; Hohenwarter, A.; Catoor, D.; Chang, E. H.; George, E. P.; Ritchie, R. O. A Fracture-Resistant High-Entropy Alloy for Cryogenic Applications. Science 2014, 345, $1153-1158$.

(36) Kim, S.-H.; Kim, H.; Kim, N. J. Brittle Intermetallic Compound Makes Ultrastrong LowDensity Steel with Large Ductility. Nature 2015, 518, 77-79.

(37) Dalton, N.; Lynch, R. P.; Collins, M. N.; Culebras, M. Thermoelectric Properties of Electrospun Carbon Nano Fibres Derived from Lignin. Int. J. Biol. Macromol. 2019, 121, $472-479$.

(38) Tang, Q.; Fang, L.; Wang, Y.; Zou, M.; Guo, W. Anisotropic Flexible Transparent Films from Remaining Wood Microstructures for Screen Protection and AgNW Conductive 
Substrate. Nanoscale 2018, 10, 4344-4353.

(39) Bi, Z.; Li, T.; Su, H.; Ni, Y.; Yan, L. Transparent Wood Film Incorporating Carbon Dots as Encapsulating Material for White Light-Emitting Diodes. ACS Sustain. Chem. Eng. 2018, 6, 9314-9323.

(40) Jung, Y. H.; Chang, T.-H.; Zhang, H.; Yao, C.; Zheng, Q.; Yang, V. W.; Mi, H.; Kim, M.; Cho, S. J.; Park, D.-W.; Jiang, H.; Lee, J.; Qiu, Y.; Zhou, W.; Cai, Z.; Gong, S.; Ma, Z. High-Performance Green Flexible Electronics Based on Biodegradable Cellulose Nanofibril Paper. Nat. Commun. 2015, 6, 7170.

(41) Okahisa, Y.; Yoshida, A.; Miyaguchi, S.; Yano, H. Optically Transparent WoodCellulose Nanocomposite as a Base Substrate for Flexible Organic Light-Emitting Diode Displays. Compos. Sci. Technol. 2009, 69, 1958-1961.

(42) Dai, S.; Chu, Y.; Liu, D.; Cao, F.; Wu, X.; Zhou, J.; Zhou, B.; Chen, Y.; Huang, J. Intrinsically Ionic Conductive Cellulose Nanopapers Applied as All Solid Dielectrics for Low Voltage Organic Transistors. Nat. Commun. 2018, 9, 2737.

(43) Koga, H.; Nogi, M.; Komoda, N.; Nge, T. T.; Sugahara, T.; Suganuma, K. Uniformly Connected Conductive Networks on Cellulose Nanofiber Paper for Transparent Paper Electronics. NPG Asia Mater. 2014, 6, e93.

(44) Zhu, M.; Jia, C.; Wang, Y.; Fang, Z.; Dai, J.; Xu, L.; Huang, D.; Wu, J.; Li, Y.; Song, J.; Yao, Y.; Hitz, E.; Wang,Y.; Hu, L. Isotropic Paper Directly from Anisotropic Wood: TopDown Green Transparent Substrate Toward Biodegradable Electronics. ACS Appl. Mater. Interfaces 2018, 10, 28566-28571.

(45) Li, T.; Li, S. X.; Kong, W.; Chen, C.; Hitz, E.; Jia, C.; Dai, J.; Zhang, X.; Briber, R.; Siwy, Z.; Reed, M.; Hu, L. A Nanofluidic Ion Regulation Membrane with Aligned Cellulose Nanofibers. Sci. Adv. 2019, 5, 4238.

(46) Frey, M.; Widner, D.; Segmehl, J. S.; Casdorff, K.; Keplinger, T.; Burgert, I. Delignified and Densified Cellulose Bulk Materials with Excellent Tensile Properties for Sustainable 
Engineering. ACS Appl. Mater. Interfaces 2018, 10, 5030-5037.

(47) Yano, H.; Hirose, A.; Collins, P. J.; Yazaki, Y. Effects of the Removal of Matrix

Substances as a Pretreatment in the Production of High Strength Resin Impregnated Wood Based Materials. J. Mater. Sci. Lett. 2001, 20, 1125-1126.

(48) Shams, M. I.; Yano, H.; Endou, K. Compressive Deformation of Wood Impregnated with Low Molecular Weight Phenol Formaldehyde (PF) Resin III: Effects of Sodium Chlorite Treatment. J. Wood Sci. 2005, 51, 234-238.

(49) Shams, M. I.; Yano, H. Development of Selectively Densified Surface Laminated Wood Based Composites. Eur. J. Wood Wood Prod. 2009, 67, 169-172.

(50) Frey, M.; Schneider, L.; Masania, K.; Keplinger, T.; Burgert, I. Delignified WoodPolymer Interpenetrating Composites Exceeding the Rule of Mixtures. ACS Appl. Mater. Interfaces 2019, 11, 35305-35311.

(51) Song, J.; Chen, C.; Wang, C.; Kuang, Y.; Li, Y.; Jiang, F.; Li, Y.; Hitz, E.; Zhang, Y.; Liu, B.; Gong, A.; Bian, H.; Zhu, J.Y.; Zhang, J.; Li, J.; Hu, L. Superflexible Wood. ACS Appl. Mater. Interfaces 2017, 9, 23520-23527. 